\title{
Techno-Economic Analysis of Hydrogen and Electricity Production by Biomass Calcium Looping Gasification
}

\author{
Abdul Rahim Shaikh ${ }^{1}{ }^{\mathbb{D}}$, Qinhui Wang ${ }^{1, *}$, Long Han ${ }^{2, *}{ }^{\circledR}$, Yi Feng ${ }^{1}$, Zohaib Sharif ${ }^{1}$, Zhixin Li ${ }^{1}$, Jianmeng Cen ${ }^{1}$ \\ and Sunel Kumar ${ }^{1}$ (D) \\ 1 State Key Laboratory of Clean Energy Utilization, Zhejiang University, Hangzhou 310027, China; \\ shaikh@zju.edu.cn (A.R.S.); 21427124@zju.edu.cn (Y.F.); zohaibsharif@zju.edu.cn (Z.S.); \\ lzx19690609@163.com (Z.L.); jmcen@zju.edu.cn (J.C.); sunelkotak@zju.edu.cn (S.K.) \\ 2 Institute of Energy and Power Engineering, College of Mechanical Engineering, \\ Zhejiang University of Technology, Chaowang Rd. 18, Hangzhou 310014, China \\ * Correspondence: qhwang@zju.edu.cn (Q.W.); longhan@zjut.edu.cn (L.H.)
}

check for updates

Citation: Shaikh, A.R.; Wang, Q.;

Han, L.; Feng, Y.; Sharif, Z.; Li, Z.; Cen, J.; Kumar, S. Techno-Economic Analysis of Hydrogen and Electricity Production by Biomass Calcium Looping Gasification. Sustainability 2022, 14, 2189. https://doi.org/ $10.3390 /$ su14042189

Academic Editor: Giovanni Esposito

Received: 10 January 2022 Accepted: 8 February 2022 Published: 15 February 2022

Publisher's Note: MDPI stays neutral with regard to jurisdictional claims in published maps and institutional affiliations.

Copyright: (c) 2022 by the authors. Licensee MDPI, Basel, Switzerland. This article is an open access article distributed under the terms and conditions of the Creative Commons Attribution (CC BY) license (https:/ / creativecommons.org/licenses/by/ $4.0 /)$.

\begin{abstract}
Combined cycle, biomass calcium looping gasification is proposed for a hydrogen and electricity production (CLGCC-H) system. The process simulation Aspen Plus is used to conduct techno-economic analysis of the CLGCC-H system. The appropriate detailed models are set up for the proposed system. Furthermore, a dual fluidized bed is optimized for hydrogen production at $700{ }^{\circ} \mathrm{C}$ and 12 bar. For comparison, calcium looping gasification with the combined cycle for electricity (CLGCC) is selected with the same parameters. The system exergy and energy efficiency of CLGCC-H reached as high as $60.79 \%$ and $64.75 \%$, while the CLGCC system had $51.22 \%$ and $54.19 \%$. The IRR and payback period of the CLGCC-H system, based on economic data, are calculated as $17.43 \%$ and 7.35 years, respectively. However, the CLGCC system has an IRR of $11.45 \%$ and a payback period of 9.99 years, respectively. The results show that the calcium looping gasification-based hydrogen and electricity coproduction system has a promising market prospect in the near future.
\end{abstract}

Keywords: calcium looping gasification; $\mathrm{CO}_{2}$ capture; biomass; hydrogen; combined cycle; techno-economic analysis

\section{Introduction}

Currently, the production of hydrogen from fossil fuels has experienced increased research attention because of the ecofriendly nature of hydrogen utilization. Hydrogen is widely used in different areas such as ammonia production, oil refining, and production of chemicals, but limited hydrogen utilization constrains its further use. The expected availability of hydrogen can replace gasoline fuel in transportation and thermal power generation, resulting in less emissions [1,2]. Globally, hydrogen production is $70 \mathrm{Mt} /$ year; $23 \%$ is contributed by coal gasification and $76 \%$ by natural gas reforming through the steam methane reforming process [3]. In contrast, the remaining production comes from different methods such as electrolysis, solar, and biological processes. The amount of coal consumed for hydrogen production is $107 \mathrm{Mt}$ ( $2 \%$ of global coal use), and natural gas accounts for $205 \mathrm{Gm}^{3}$ (6\% of global natural gas), generating $830 \mathrm{Mt} \mathrm{CO}_{2}$ emissions, which are $2 \%$ of total global emissions [3]. Hence, an increase in hydrogen demand would lead to additional $\mathrm{CO}_{2}$ emissions; however, without carbon capture and storage (CCS), the existing technology infrastructure cannot meet the $2{ }^{\circ} \mathrm{C}$ Paris Agreement goal for climate change $[1,2,4]$.

Biomass gasification can be an alternate technology for hydrogen production, considering hydrogen's benefits in saving the environment and its economic feasibility [5]. The hydrogen produced from biomass gasification contributes a minor part of $\mathrm{CO}_{2}$ emission, since biomass is a renewable resource that consumes $\mathrm{CO}_{2}$ during its growth and releases $\mathrm{CO}_{2}$ from the gasification process [6]. Many countries realized that the " $\mathrm{H}_{2}$ economy" will be a potential solution to meet global energy demand and reduce fossil fuel use [7]. 
Market forecast shows that demand for hydrogen will increase in the near future with $5-10 \%$ growth per year, from 50 to $82 \mathrm{Mt}$ by 2050 . Globally, transportation (especially air and road) accounts for about a quarter of the net of carbon dioxide emissions [8-10]. Industrial activities by 2050 will increase the demand for $\mathrm{H}_{2}$, resulting in $\mathrm{H}_{2}$ production projected to rise, especially for steel and ammonia production, by about $2 \mathrm{EJ} / \mathrm{a}$ for each activity, while hydrogen-powered vehicles could produce approximately 22 EJ/a [11]. However, renewable resources contribute only $2 \%$ for hydrogen production; the main contribution comes from water electrolysis. There is no active use of biomass on an industrial scale [6,12], which creates an opportunity to convert biomass into a valuable source of hydrogen. Research has been carried out to assess the economic pros and cons of prevalent and upcoming technologies in terms of low $\mathrm{CO}_{2}$ emissions resulting from hydrogen production, such as gas switching-reforming [13], membrane-assisted fluidized-bed reactors [14], chemical looping reform (CLR) [15-17], autothermal reform (ATR) with CCS [16], steam methane reform (SMR) with chemical looping combustion (CLC) [16], and SMR with amine scrubbing [15], to evaluate the economic performance for low-emission hydrogen production; the average cost of hydrogen was 1.6-3.2 USD $/ \mathrm{kg}$. Kathe et al. investigated the thermodynamic limitations and energy consumption of the natural gas CLR hydrogen generation process using an iron-based oxygen carrier (OC) [18]. Adiya et al. investigated using $\mathrm{NiO}$ on $\mathrm{Al}_{2} \mathrm{O}_{3}$ and $\mathrm{NiO}$ on $\mathrm{CaO} / \mathrm{Al}_{2} \mathrm{O}_{3}$ as catalysts and $\mathrm{OC}$ in a packed bed reactor for shale gas chemical looping steam reforming for hydrogen production, which showed a high fuel conversion and yield under operating temperatures of 700 and $750{ }^{\circ} \mathrm{C}[19,20]$. Techno-economics analysis of three hydrogen production processes was investigated by Chisalita and Cormos [21], which concluded that efficient hydrogen production via chemical looping is the most efficient with low maintenance and operating costs. Furthermore, by utilizing iron oxide $(\mathrm{OC})$ and $\mathrm{CaO}$ as $\mathrm{CO}_{2}$ adsorbents, a new integration of sorption-enhanced CLR and water splitting for hydrogen generation was proposed by Saithong et al. [22]. Thus, utilizing calcium looping technology for biomass to hydrogen and power production with in situ $\mathrm{CO}_{2}$ capture is projected to improve thermodynamic process efficiency, provide economic advantage, and achieve negative carbon emission. A comprehensive investigation of the calcium looping mechanism is planned.

Hosseini and Wahid [9] reported that supercritical water gasification of biomass is one of the most cost-effective thermochemical processes since wet biomass is fed directly into the gasifier without prior drying. Furthermore, generation at high pressure lowered the cost of hydrogen storage. Udomsirichakorn and Salam [23] studied calcium oxide in chemical looping of biomass gasification for hydrogen generation, and concluded that biomass gasification is a viable, environmentally benign, and long-term option for hydrogen generation, satisfying the environmental requirement. Adams and Barton [24] offered techno-economic studies for several technologies that were used to develop efficient polygeneration systems for processing coal and natural gas. Ahmed et al. [25] proposed an integrated model of coal gasification with SMR to enhance $\mathrm{H}_{2}$ production by utilizing syngas heat and steam from the gasification process. Furthermore, Ahmed et al. [26] conducted a techno-economic analysis of both traditional coal and the integrated coal gasification and SMR process, establishing that the integrated model is more efficient. Moreover, Cormos [27] investigated techno-economic analysis of coal-fired combustion and gasification power plants having post-combustion $\mathrm{CO}_{2}$ capture by utilizing a calcium looping cycle. It was concluded that calcium looping has good application potential in combustion-based power plants with 90\% carbon capturing rate, low energy penalties, and high efficiency. Cormos [28] carried out a study on biomass direct chemical looping for cogeneration of hydrogen and power. This process provides high energy efficiencies and a carbon capture rate higher than $99 \%$, which contrasts with various other $\mathrm{CO}_{2}$ capture techniques (e.g., gas-liquid absorption). The economic factors revealed the reduction in $\mathrm{CO}_{2}$ capture cost penalty for proposed technology in contrast to gas-liquid absorption. Jiang et al. [29] analyzed the thermodynamic and economic assessment of two chemical looping cycles schemes with conventional biomass gasification. The study provides a detailed comparison of chemical looping and 
calcium looping with conventional biomass gasification in terms of capital cost, operating cost, and the levelized cost of energy. Calcium looping and chemical looping proved to be better options for the environment than conventional biomass gasification due to high carbon capturing efficiency.

In the literature, none of the studies have investigated the economic performance of the combined cycle of calcium looping gasification (CLGCC) with duel fluidized bed (DFB) in situ carbon capture or hydrogen and power generation by calcium looping gasification (CLGCC-H), which can offer near-zero or negative $\mathrm{CO}_{2}$ emissions. Furthermore, all previous studies on the integration of chemical looping with IGCC and reforming processes were based on the additional use of steam and $\mathrm{CO}_{2}$ to perform reforming processes. The current study mainly aimed to (1) propose and simulate a novel DFB, CLGCC-H, and CLGCC system with a CaO-based capture system, analyze the impact of different parameters on the system performance by Aspen Plus, and (2) to perform a comprehensive techno-economic data evaluation for both systems and to provide a reference framework for commercial operation.

\section{Modeling and Simulation}

\subsection{Hydrogen and Electricity Production by Calcium Looping Gasification Process}

The calcium looping gasification with the combined cycle for electricity generation (CLGCC) and calcium looping gasification with the combined cycle for hydrogen and electricity generation (CLGCC-H) schema mainly comprise flowing prime blocks in sequence, i.e., dual fluidized bed (gasifier and combustor), ASU, waste heat recovery (WHR), heat recovery steam generator (HRSG), gas cleaning (scrubber), acid gas removal unit (Selexol), elemental sulfur recovery unit (Claus), gas turbine (GT), and steam turbine (ST). The block diagram of CLGCC and CLGCC-H is shown in Figures 1 and 2. For hydrogen separation, the pressure swing absorption (PSA) is an additional unit after the selexol unit. Table 1 represent a design assumption for the CLGCC and CLGCC-H system.

Table 1. Design assumption for CLGCC and CLGCC-H.

\begin{tabular}{|c|c|c|}
\hline Unit/Component/System & Modeling Unit & Parameters \\
\hline Gasification Reactor & RYield, RGibbs (Reactor) & $\begin{array}{l}\text { Biomass flow rate }=131.16 \text { ton } / \mathrm{h} \\
\text { Temperature: } 700{ }^{\circ} \mathrm{C} \\
\text { Pressure: } 12 \text { bar }\end{array}$ \\
\hline Combustor Reactor & RGibbs (Reactor) & $\begin{array}{l}\text { Temperature: } 1000^{\circ} \mathrm{C} \\
\text { Pressure: } 12 \text { bar }\end{array}$ \\
\hline Air Separation Unit (ASU) & HeatX, Compr & $\begin{array}{l}\mathrm{O}_{2}=94.5 \% \text { (vol) } \\
\text { Power consumption: } 235 \mathrm{~kW} / \mathrm{t}\end{array}$ \\
\hline $\mathrm{H}_{2} \mathrm{~S}$ removal Section & RadFrac & $\begin{array}{l}\text { Selexol solvent } \\
\mathrm{H}_{2} \mathrm{~S} \text { removal } \sim 99.9 \% \\
\text { Absorber and regeneration stages: } 12 \text { each with } \\
\text { thermal regeneration. }\end{array}$ \\
\hline PSA & Sep2 & $\begin{array}{l}\text { Hydrogen separation } \sim 99.99 \% \\
\text { Power consumption: } 5.63 \mathrm{~kW} / \mathrm{ft}^{3} / \mathrm{m}\end{array}$ \\
\hline Pump Efficiency & Pump & $85 \%$ \\
\hline Compressor Efficiency & Compr & $82 \%$ \\
\hline Steam Turbine Eff (Isentropic) & Compr & $87.50 \%$ \\
\hline Gas Turbine Eff (Adiabatic) & Compr & $\begin{array}{l}\text { TIT }\left(\text { Turbine inlet temp) }=\sim 1550{ }^{\circ} \mathrm{C}\right. \\
\text { TOT }\left(\text { Turbine outlet temp) }=\sim 570{ }^{\circ} \mathrm{C}\right. \\
\text { Adiabatic efficiency }=85 \%\end{array}$ \\
\hline HRSG & HeatX, Compr & $\begin{array}{l}124 / 40 / 20 / 0.069 \text { (bars) } \\
\Delta \mathrm{T}_{\min }=10^{\circ} \mathrm{C}\end{array}$ \\
\hline
\end{tabular}

Pine sawdust is used as fuel in this research; the chemical (ultimate and proximate) analysis results are recorded in Table 2. After preparation, fuel is fed to the gasifier, which reacts with the steam to produce hydrogen-rich syngas. The hydrogen-rich syngas is piped 
to the waste heat recovery for steam generation. The unburned char from the gasifier and clean syngas after scrubber is combusted in a combustor with $\mathrm{O}_{2}$ coming from ASU, which produces heat for gasifier needs and $\mathrm{CaO}$ regeneration, and $\mathrm{CO}_{2}$-rich flue gas produced in the combustor is piped to $\mathrm{CO}_{2}$ storage after cooling. The flowsheet of the CLGCC is shown in Figure 3. After cleaning processes, the $\mathrm{H}_{2}$-rich syngas is routed for hydrogen and electricity through PSA or without PSA for power generation. The hydrogen separated is at $99.9 \mathrm{vol} \%$, and the remaining syngas is combusted in a gas turbine after the GT steam cycle is used for power generation.

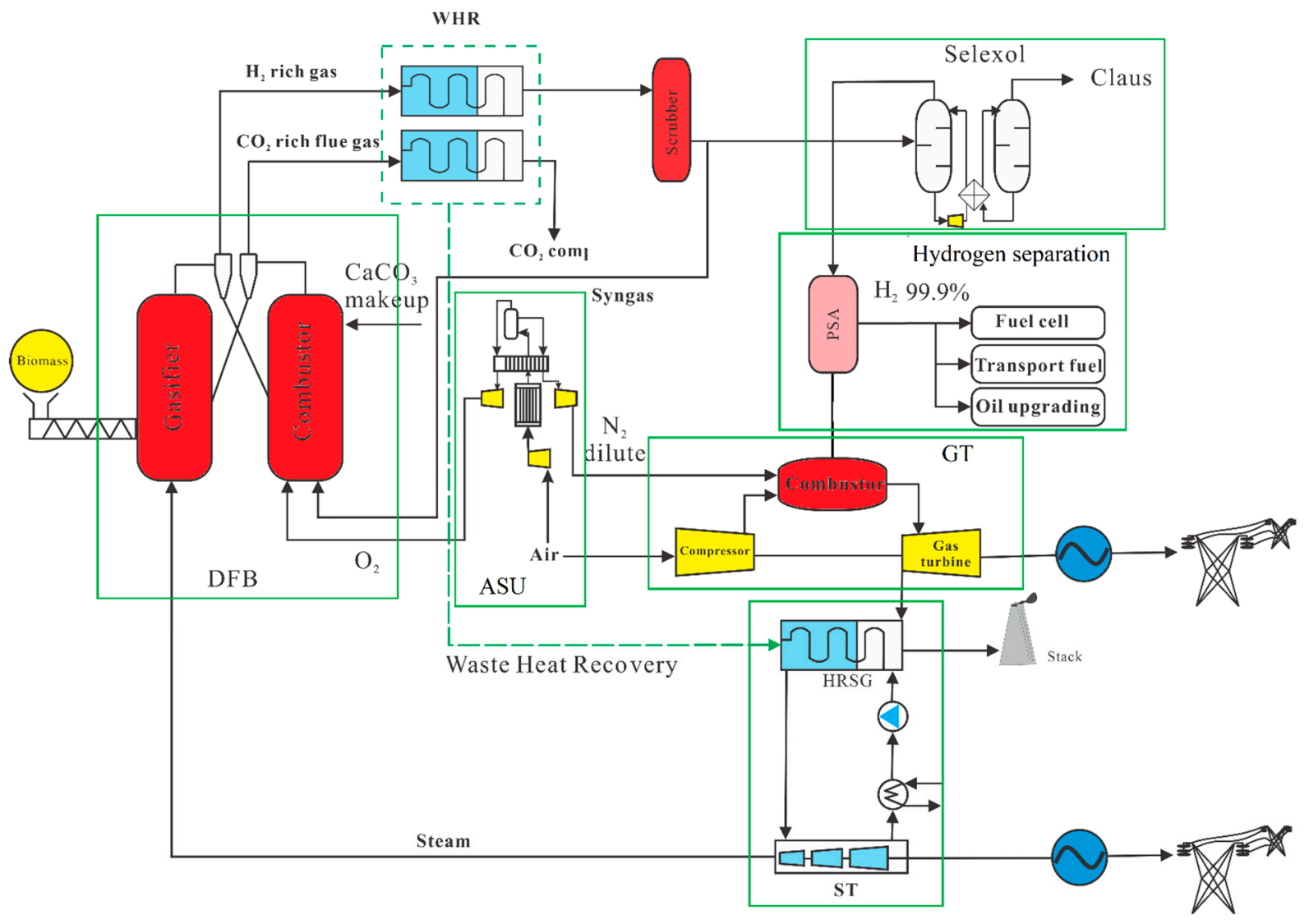

Figure 1. The calcium looping gasification with the combined cycle for hydrogen and electricity generation (CLGCC-H).

Table 2. Chemical analyses of pine sawdust.

\begin{tabular}{lcc}
\hline & & Pine Sawdust \\
\hline \multirow{4}{*}{ Ultimate analysis } & $\mathrm{C}$ & 52.53 \\
& $\mathrm{H}$ & 6.08 \\
& $\mathrm{O}$ & 39.04 \\
& $\mathrm{~N}$ & 0.09 \\
& $\mathrm{~S}$ & 0.55 \\
Proximate analysis & $\mathrm{A}$ & 1.70 \\
& $\mathrm{~V}$ & 85.15 \\
& $\mathrm{FC}$ & 13.15 \\
& $\mathrm{~A}$ & 1.70 \\
& $\mathrm{LHV}(\mathrm{kJ} / \mathrm{kg})$ & 19,853 \\
& Moisture & 2.07 \\
\hline
\end{tabular}




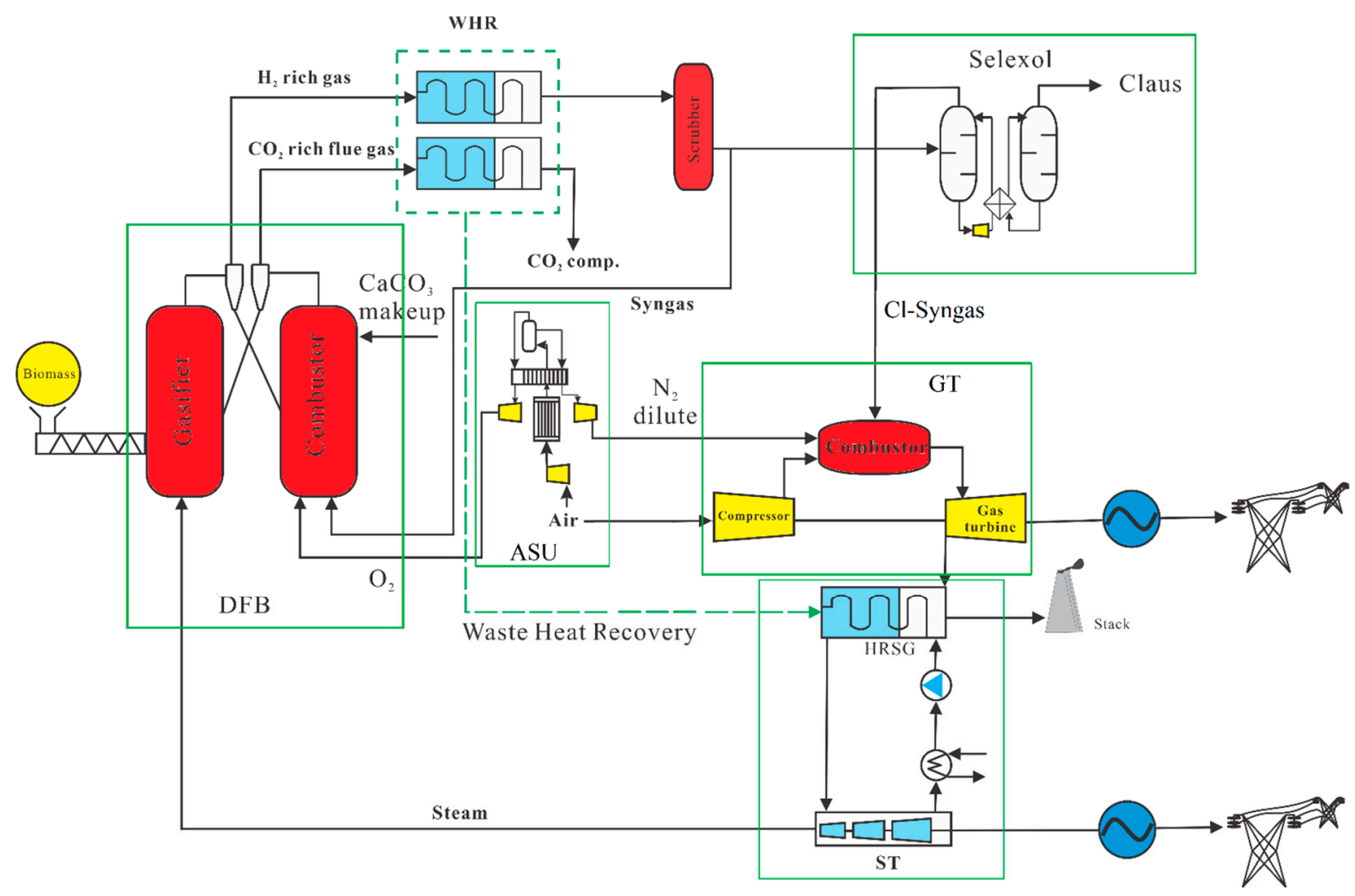

Figure 2. The calcium looping gasification with the combined cycle for electricity generation (CLGCC).

\subsubsection{Dual Fluidized Bed Calcium Looping Gasification}

Figure 4 depicts the layout of the simplified process for $\mathrm{H}_{2}$ production by DFB biomass steam gasification, consisting of gasification and combustor reactors. The carbonous fuel is fed into a fluidized bed that uses steam for fluidization. The gasification occurred at a temperature of $700{ }^{\circ} \mathrm{C}$, with 10 bar pressure, and recirculated $\mathrm{CaO}$ was used as a $\mathrm{CO}_{2}$ absorbent and formed $\mathrm{CaCO}_{3}$. Residual char and $\mathrm{CaCO}_{3}$ from the gasifier after cyclone enter into the combustor, where char and dehydrated syngas from the gasifier (if required) is combusted with oxygen to reform $\mathrm{CaO}$ from $\mathrm{CaCO}_{3}$, producing $\mathrm{CO}_{2}$-rich flue gas at a combustion temperature of $1000{ }^{\circ} \mathrm{C}$ and 12 bar pressure. Additionally, $\mathrm{CO}_{2}$ is captured in DFB by the calcium looping process, based on Le Chatelier's Principle. Moreover, enhanced hydrogen production reactions, such as water-gas, water-gas-shift, and steam methane reforming, are all based on the same principle.

The energy required for gasification and the rate at which the bed material circulates influences the temperature differential between the combustion and gasification zones. The quantity of unburnt char that exits the gasifier with the bed material and the gasification temperature are two more factors that have an energy impact. This system is intrinsically auto-stabilizing because the decrease in the gasification temperature results in a higher quantity of residual char and, as an outcome, the combustion reactor has more fuel. Thus, it feeds more energy into the gasification zone, which adjusts the temperature accordingly. The process produces two distinct gas streams, $\mathrm{H}_{2}$-rich syngas from the gasifier reactor and $\mathrm{CO}_{2}$-rich flue gas from the combustor reactor, at high temperatures. The following are the significant reactions that occur in a dual fluidized bed. 


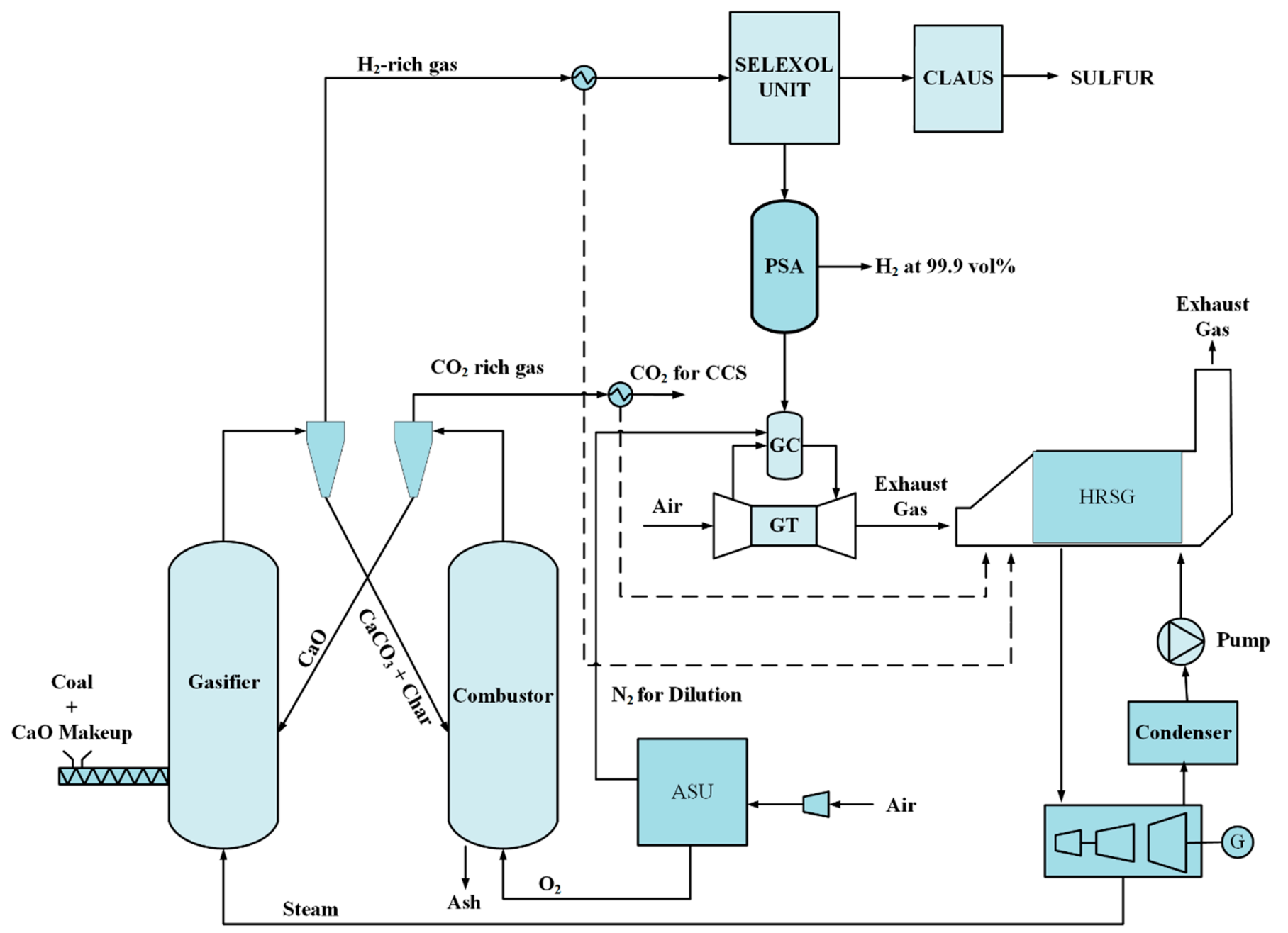

Figure 3. The flowsheet of the calcium looping gasification with the combined cycle for hydrogen and electricity generation (CLGCC-H).

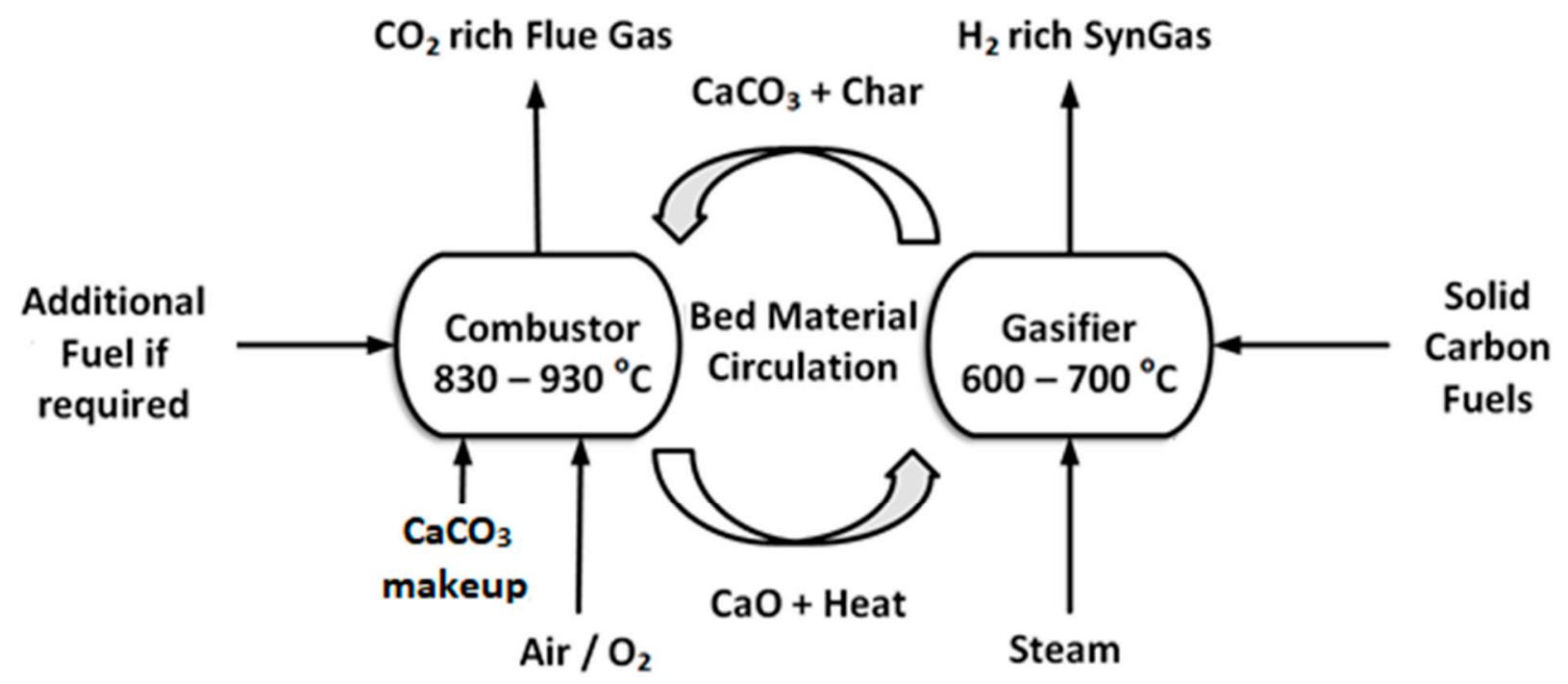

Figure 4. Basic concept of calcium looping gasification with $\mathrm{CaO}$ as bed material. 
Gasifier Reactor $\left(600-700^{\circ} \mathrm{C}\right)$,

Water gas:

$$
\mathrm{C}+\mathrm{H}_{2} \mathrm{O} \rightleftarrows \mathrm{CO}+\mathrm{H}_{2} \quad \Delta \mathrm{H}_{\mathrm{R}}^{650 / 900}=136 \mathrm{~kJ} / \mathrm{mol}
$$

Hydro-gasification or methanation:

$$
\begin{aligned}
& \mathrm{C}+2 \mathrm{H}_{2} \rightleftarrows \mathrm{CH}_{4} \Delta \mathrm{H}_{\mathrm{R}}^{650 / 900}=-88 \mathrm{~kJ} / \mathrm{mol} \\
& \mathrm{C}+\mathrm{CO}_{2} \rightleftarrows 2 \mathrm{CO} \Delta \mathrm{H}_{\mathrm{R}}^{650 / 900}=171 \mathrm{~kJ} / \mathrm{mol}
\end{aligned}
$$

Methane steam reforming:

$$
\mathrm{CH}_{4}+\mathrm{H}_{2} \mathrm{O} \rightleftarrows \mathrm{CO}+3 \mathrm{H}_{2} \Delta \mathrm{H}_{\mathrm{R}}^{650 / 900}=224 \mathrm{~kJ} / \mathrm{mol}
$$

Water-gas shift:

$$
\mathrm{CO}+\mathrm{H}_{2} \mathrm{O} \rightleftarrows \mathrm{CO}_{2}+\mathrm{H}_{2} \Delta \mathrm{H}_{\mathrm{R}}^{650 / 900}=-36 \mathrm{~kJ} / \mathrm{mol}
$$

Hydro-carbon steam reforming:

$$
\mathrm{C}_{\mathrm{x}} \mathrm{H}_{\mathrm{y}}+\mathrm{xH}_{2} \mathrm{O} \rightleftarrows \mathrm{xCO}+(\mathrm{x}+0.5) \mathrm{H}_{2}>0 \mathrm{~kJ} / \mathrm{mol}
$$

Hydro-carbon dry reforming:

$$
\mathrm{C}_{\mathrm{x}} \mathrm{H}_{\mathrm{y}}+2 \mathrm{xCO}_{2} \rightleftarrows 2 \mathrm{xCO}+0.5 \mathrm{yH}_{2}>0 \mathrm{~kJ} / \mathrm{mol}
$$

Carbonation:

$$
\mathrm{CaO}+\mathrm{CO}_{2} \rightleftarrows \mathrm{CaCO}_{3} \Delta \mathrm{H}_{\mathrm{R}}^{650 / 900}=-170 \mathrm{~kJ} / \mathrm{mol}
$$

Combustor Reactor $\left(830-930^{\circ} \mathrm{C}\right)$,

CO oxidation:

$$
\mathrm{CO}+0.5 \mathrm{O}_{2} \rightarrow \mathrm{CO}_{2} \Delta \mathrm{H}_{\mathrm{R}}^{650 / 900}=-282 \mathrm{~kJ} / \mathrm{mol}
$$

Partial oxidation of carbon:

$$
\mathrm{C}+0.5 \mathrm{O}_{2} \rightarrow \mathrm{CO} \Delta \mathrm{H}_{\mathrm{R}}^{650 / 900}=-113 \mathrm{~kJ} / \mathrm{mol}
$$

Total oxidation of carbon:

$$
\mathrm{C}+\mathrm{O}_{2} \rightarrow \mathrm{CO}_{2} \Delta \mathrm{H}_{\mathrm{R}}^{650 / 900}=-395 \mathrm{~kJ} / \mathrm{mol}
$$

Calcination:

$$
\mathrm{CaCO}_{3} \rightleftarrows \mathrm{CaO}+\mathrm{CO}_{2} \Delta \mathrm{H}_{\mathrm{R}}^{650 / 900}=166 \mathrm{~kJ} / \mathrm{mol}
$$

\subsubsection{Air Separation Unit}

The main purpose of the air separation unit (ASU), being a large-scale modern plant, is to feed highly pure $\mathrm{O}_{2}$ to the gasification unit employing combined distillation and cryogenic air separation [30]. In practice, initially, the compressed liquefied air at 5-6 bar, is cooled using an expander to achieve liquefaction. Then, it is fed into the oxygen-nitrogen separation tower, having two parts, i.e., upper and lower. The upper tower's bottom is used to distill oxygen, the separation of $\mathrm{O}_{2}$ from the $\mathrm{N}_{2}$ and Ar, taking place at the base of the lower tower. The combustor unit employs $\mathrm{O}_{2}(94.5 \mathrm{~mol} \%)$ as an oxidant, while as stripping gas highly pure $\mathrm{N}_{2}$ is utilized and $\mathrm{N}_{2}$ is used for syngas dilution in the selexol unit and gas turbine, respectively. To thermodynamically simulate the ASU model, the 
Peng-Rob EOS method was opted, whereas to model the separation tower, a RadFrac block was employed.

\subsubsection{Heat Recovery and Water Scrubbing}

The heavy particles are separated in the cyclone; heat is then recovered in HRSG from hot $\mathrm{H}_{2}$-rich syngas, rich in fine particles. After heat recovery, syngas is fed to water scrubbing to eliminate fine particles. MHeatX and Flash2 models of Aspen Plus software are employed to simulate the heat recovery and fine particle trapping, assuming that the efficiency of fine particle separation is $100 \%$. Then the clean and cool syngas, with a temperature of $45^{\circ} \mathrm{C}$, is fed to the selexol unit, while $\mathrm{CO}_{2}$-rich gas at $100^{\circ} \mathrm{C}$ flows to the $\mathrm{CO}_{2}$ compression unit for subsequent storage.

\subsubsection{Selexol Unit}

Chemical and physical solvents are commonly employed in the desulfurization process on a commercial scale to remove the acid gas, particularly for $\mathrm{H}_{2} \mathrm{~S}$. Since the physical absorption process is more energy-efficient at a very high concentration of $\mathrm{H}_{2} \mathrm{~S}$ [31], physical solvents, viz., dimethyl ether of polyethylene glycol (Coastal AGR ${ }^{\circledR}$ or DEPG; Selexol ${ }^{\mathrm{TM}}$ ), methanol (Rectisol ${ }^{\circledR}$ ), n-methyl-2-pyrrolidone (NMP, Purisol ${ }^{\circledR}$ ), and propylene carbonate (Fluor Solvent ${ }^{\mathrm{TM}}$ ) are advantageously preferred over the chemical solvents [32]. Specifically, as the Rectisol ${ }^{\circledR}$ is a complex process, it therefore has a higher operational cost. Further, the Fluor Solvent ${ }^{\mathrm{TM}}$ process is preferred due to having little or no $\mathrm{H}_{2} \mathrm{~S}$ in the syngas [32]. In the selexol unit, DEPG is adopted as a solvent to remove $\mathrm{H}_{2} \mathrm{~S}$.

The complex configurations of $\mathrm{H}_{2} \mathrm{~S}$ absorbers and the stripper that generates DEPG, causing a comparatively slow convergence speed, Sep block model is employed, representing the single-stage Selexol ${ }^{\mathrm{TM}}$ process to remove $\mathrm{H}_{2} \mathrm{~S}$ from the water scrubbed clean syngas. The perturbed-chain statistical associating fluid (PC-SAFT) property method is chosen $[31,33]$. The concentration of $\mathrm{H}_{2} \mathrm{~S}$-rich gas and the clean gas is employed by Field et al. [32]. Then, to generate elemental sulfur, acid gas-rich $\mathrm{H}_{2} \mathrm{~S}$ is fed to a Claus/SCOT plant [34]. The Claus process allows for a split-flow configuration with a portion of the $\mathrm{H}_{2} \mathrm{~S}$ supply going to the furnace and the rest bypassing it to mix in the first catalytic reactor. In the Claus process, sulfur condensers are used to eliminate sulfur, allowing the Claus equilibrium reaction to occur in the converter reactor. After two stages of condensers and converters, the remaining $\mathrm{SO}_{2}$ is converted back to $\mathrm{H}_{2} \mathrm{~S}$ in the Tail Gas Thermal Unit (TGTU), allowing the tail gas to be recycled back into the selexol unit. Below is a summary of the responses $[35,36]$.

\subsubsection{Pressure Swing Adsorption (PSA) Unit}

As a modern gas separation technology, comparatively, PSA is extensively utilized to achieve hydrogen purification, employing a physical adsorption technique [37]. It functions at an average temperature and varied pressure levels to remove impurities in hydrogen through an adsorbent. The PSA hydrogen production, an operationally stable process, is accomplished in three stages: high-pressure adsorption, low-pressure desorption, and pressure boosting. It helps to remove various impurities from the mixed gas simultaneously to produce a highly pure product. Firstly, the $\mathrm{H}_{2}$-rich mixed gas is introduced into the adsorbent bed from the bottom at high pressure, making adsorption of impurities, viz., $\mathrm{CO}, \mathrm{CO}_{2}$, and $\mathrm{CH}_{4}$ are weakly adsorbed components, resulting in hydrogen separation. Secondly, based on the efficiency of the adsorbed components, the adsorbent is reproduced by either product hydrogen purging or reverse pressure relief method to maintain the quality of the products. Following this, the pressure in the adsorbent bed is readjusted. Commonly, at least two or more adsorbent beds are utilized for sustainable production of the hydrogen cycle. For modeling the PSA, RK-Soave was adopted owing to its thermodynamic nature, whereas adsorption tower was simulated by adopting Sep block. 


\subsubsection{The Gas Turbine (GT) and Steam Turbine (ST)}

Both the gas and steam turbine models are set up by using Aspen Plus. The clean syngas from selexol/PSA is directed to the combustion chamber. The exhaust gas is used in the gas turbine to generate electricity. Compressed air is also introduced to accomplish the combustion process. Additionally, separated nitrogen is mixed with the clean syngas to constrain the temperature at the gas turbine inlet to $1550{ }^{\circ} \mathrm{C}$ and to avoid the formation of nitrous oxides. Then, the exhaust from the gas turbine is fed into the heat recovery steam generator (HRSG), with additional heat being recirculated from different parts of the plant for steam production. A steam cycle occurs with the subcritical power generation technology, as the temperature of exhaust gas from the gas turbine is comparatively low $\left(\sim 570{ }^{\circ} \mathrm{C}\right)$. This superheated steam is used to drive the steam turbine, which generates additional electricity for the grid. Table 3 shows the specific parameters of the combined cycle (GT and ST). For the material property analysis, the PR-BM property package is utilized for analysis. In contrast, STEAM-TA is adopted for water and steam accessories including pumps and steam turbines.

Table 3. Specific parameters for combined cycle (GT and ST).

\begin{tabular}{llll}
\hline Facility & Parameter & Unit & Value \\
\hline Air Compressor & Outlet Pressure & bar & 21.2 \\
GT & Inlet Temperature & ${ }^{\circ} \mathrm{C}$ & 1550 \\
& Outlet Temperature & ${ }^{\circ} \mathrm{C}$ & 570 \\
Steam Turbine & Inlet Temperature of HP & ${ }^{\circ} \mathrm{C}$ & 520 \\
& Inlet Pressure of HP & bar & 124 \\
& Reheating Temperature & ${ }^{\circ} \mathrm{C}$ & 520 \\
& Reheating Pressure & bar & 40 \\
& Inlet Temperature of IP & ${ }^{\circ} \mathrm{C}$ & 373.55 \\
& Inlet Pressure of IP & bar & 20 \\
Pump & Outlet Pressure of LP & bar & 0.069 \\
\hline
\end{tabular}

\section{Techno-Economic Evaluation}

The production of hydrogen and electricity from biomass by calcium looping gasification process was realized using Aspen Plus; techno-economic evaluation was carried out using the simulation-based results.

\subsection{Thermodynamic Evaluation}

The first law of thermodynamics is used to determine the energy efficiency, while exergy efficiency is evaluated by the second law of thermodynamics. Energy and exergy efficiencies are simultaneously applied to investigate the hydrogen and electricity production by calcium looping gasification.

$$
\begin{aligned}
& \eta_{\text {CLGCC }-\mathrm{H}}=\frac{\mathrm{E}_{\text {net product,tot }}}{\mathrm{E}_{\text {in,tot }}} \times 100=\frac{\mathrm{m}_{\text {Biomass }} \mathrm{LHV}_{\mathrm{H}_{2}+} \mathrm{E}_{\mathrm{GT}}+\mathrm{E}_{\mathrm{ST}}-\mathrm{E}_{\mathrm{AUX}}}{\mathrm{m}_{\text {Biomass }} \mathrm{LHV}_{\text {Biomass }}} \times 100 \\
& \varepsilon_{\mathrm{CLGCC}-\mathrm{H}}=\frac{\mathrm{Ex}_{\text {net product,tot }}}{\mathrm{Ex}_{\text {in,tot }}} \times 100=\frac{\mathrm{Ex}_{\mathrm{H}_{2}+} \mathrm{Ex}_{\mathrm{GT}}+\mathrm{Ex}_{\mathrm{ST}}-\mathrm{Ex}_{\mathrm{AUX}}}{\mathrm{Ex}_{\text {Biomass }}} \times 100 \\
& \eta_{\text {CLGCC }}=\frac{E_{\text {net product,tot }}}{E_{\text {in,tot }}} \times 100=\frac{E_{G T}+E_{S T}-E_{A U X}}{m_{\text {Biomass }} L H V_{\text {Biomass }}} \times 100 \\
& \varepsilon_{\mathrm{CLGCC}}=\frac{\mathrm{Ex}_{\text {net product,tot }}}{\mathrm{Ex}_{\text {in,tot }}} \times 100=\frac{\mathrm{Ex}_{\mathrm{GT}}+\mathrm{Ex}_{\mathrm{ST}}-\mathrm{Ex}_{\mathrm{AUX}}}{\mathrm{Ex}_{\text {Biomass }}} \times 100
\end{aligned}
$$

For these equations, $\varepsilon(\%)$ and $\eta(\%)$ represent the exergy and energy efficiencies, respectively; $\mathrm{m}_{\mathrm{i}}$ denotes the flow rate of species $\mathrm{i}$, and $\mathrm{LHV}_{\mathrm{i}}$ is lower heating value of material i. $\mathrm{E}_{\mathrm{GT}}(\mathrm{MW}), \mathrm{E}_{\mathrm{ST}}(\mathrm{MW})$, and $\mathrm{E}_{\mathrm{AUX}}(\mathrm{MW})$ represent the energy of net power generation 
from the gas turbine, steam turbine, and power consumed by auxiliary equipment in the whole plant. Finally, $\mathrm{Ex}_{\mathrm{H}_{2}}(\mathrm{MW}), \mathrm{Ex}_{\mathrm{GT}}(\mathrm{MW}), \mathrm{Ex}_{\mathrm{ST}}(\mathrm{MW})$, and $\mathrm{Ex}_{\mathrm{AUX}}(\mathrm{MW})$ represent the exergy of hydrogen, net power generation from the gas turbine, steam turbine, and power consumed by auxiliary equipment in the whole plant. The exergy of biomass is calculated by Szargut's correlation [38], exergy of hydrogen is determined by Rant's equation [39].

The $\mathrm{CO}_{2}$ capture efficiency $\eta_{\text {, cs }}$ of CLGCC-H and CLGCC system is defined as:

$$
\eta_{\text {ccs }}=\frac{\mathrm{X}_{\mathrm{c} \text { in } \mathrm{CO}_{2}-\text { rich flue gas }}}{\mathrm{X}_{\mathrm{C} \text { in biomass feed }}} \times 100 \%
$$

where $\mathrm{X}_{\mathrm{c}}$ in $\mathrm{CO}_{2}$ rich gas is carbon mole flow in $\mathrm{CO}_{2}$-rich flue gas out from the combustor and $\mathrm{X}_{\mathrm{C}}$ in biomass feed is carbon mole flow through biomass feed.

\subsection{Economic Evaluation}

The fixed capital investment (FCI), payback period, and internal rate of return (IRR) are used to evaluate and highlight the economic efficiency of CLG-hydrogen and electricity, considering the cost of associated facilities, input materials, and resulting products. The FCI is determined by the scaling-up method, promoted by Sweny et al. [40].

$$
F C I=\sum_{a=0}^{b}\left[I_{a} V_{r, a}\left(\frac{C_{a}}{C_{r, a}}\right)^{S_{a}}\right]
$$

where $I_{a}, C_{a}$, and $S_{a}$ represent installation factor, scale, and scale factor of equipment in the calculated scale, respectively. $V_{r, a}$ and $C_{r, a}$ denote the reference cost and scale of equipment respectively, with $b$ as the total number of devices. The price of every piece of equipment is calculated with reference to the cost index as defined by the thermal power engineering limit design [41].

$$
\text { Cost in current year }=\cos t \text { in year } x \times \frac{\mathrm{CEPCI}_{\text {current }}}{\mathrm{CEPCI}_{\text {year } \mathrm{x}}}
$$

The effect of inflation is reported by employing the chemical engineering plant cost index (CEPCI), as given by Equation (19). The annual CEPCI for 2011, 2014, and 2017 is 585.7, 576.1, and 567.5, respectively, whereas the CEPCI for 2019 (607.5) is considered the current year CEPCI [42].

The feasibility of engineering projects is commonly evaluated based on the IRR, expressed as $[43,44]$ :

$$
\sum_{t=0}^{n} \frac{C_{t}}{(1+I R R)^{t}}=0
$$

where $C_{t}$ denotes the cash flows of the year $t$, whereas $\mathrm{n}$ represents the calculation years.

The net cash flow $C_{t}$ is calculated as per Equation (21) [44].

$$
C_{t}=C_{P}-\left((C R F(1+\alpha)+O A M) F C I+C_{F}+C_{M}\right)
$$

where $C_{P}, C_{F}$, and $C_{M}$ denotes the annual income of products, fuel cost, and material cost, respectively. OAM represents the annual operation and management cost ratio to FCI, which is $4 \%$ of FCI. Further, $\alpha$ symbolizes the interest rate during the construction period, while the CRF denotes the average annual investment ratio [45]. Table 4 summarizes the detailed information about the capital cost of all facilities.

$$
C R F=\frac{i}{1-(1+i)^{n}}
$$


The payback period is calculated as reported in [46]:

$$
\sum_{n=1}^{P_{t}} C_{t}=0
$$

where $P_{t}$ denotes the payback period and $n$ represents time.

Table 4. Plant equipment primary capital cost data.

\begin{tabular}{|c|c|c|c|c|c|}
\hline Components & Basic Cost $\left(10^{6}\right.$ USD in 2019$) *$ & Basic Scale & Scale Factor & Installation Factor & Reference \\
\hline Biomass preparation $\left(\mathrm{kg} \mathrm{s}^{-1}\right)$ & 21.11 & 23.15 & 0.7 & 1 & [47] \\
\hline $\begin{array}{c}\text { Gasifier (dual fluidized bed) biomass } \\
\text { input (MW) }\end{array}$ & 559.27 & 1198.03 & 0.6 & 1 & [28] \\
\hline $\operatorname{ASU}\left(\mathrm{O}_{2} \mathrm{~kg} \mathrm{~s}^{-1}\right)$ & 134.93 & 53.36 & 0.6 & 1 & [47] \\
\hline Selexol ( $\mathrm{t} \mathrm{d}^{-1}$ sulfur input) & 46.91 & 81 & 0.7 & 1 & [34] \\
\hline Claus/SCOT ( $\mathrm{t} \mathrm{d}^{-1}$ sulfur input) & 32.51 & 81 & 0.7 & 1 & [34] \\
\hline $\mathrm{H}_{2}$ PSA $\left(\mathrm{kmol} \mathrm{H}_{2} \mathrm{~h}^{-1}\right)$ & 17.79 & 16,616 & 0.65 & 2.56 & [44] \\
\hline $\begin{array}{l}\text { Heat exchanger }\left(\mathrm{MW}_{\text {th }}\right) \\
\text { Power island }\end{array}$ & 13.34 & 138 & 0.6 & 5 & {$[48-50]$} \\
\hline Gas turbine (net MW) & 118.36 & 276 & 0.75 & 1 & [44] \\
\hline Steam turbine and cycle (gross MW) & 57.54 & 275 & 0.67 & 2 & {$[48-50]$} \\
\hline $\mathrm{CO}_{2}$ compression unit $\left(\mathrm{m}^{3} \mathrm{~h}^{-1}\right)$ & 76.76 & $430,850.77$ & 0.67 & 1 & [51] \\
\hline
\end{tabular}

* 1 USD $=6.91 \mathrm{RMB}$ on average exchange rate in 2019 [52].

\section{Results and Discussion}

\subsection{System Validation and Optimization}

The biomass CLGCC-H and CLGCC models were verified using experimental data from our $10 \mathrm{~kW}$ system [53] and compared with other literature [54-56]. The model's conditions were found to be the same in both simulation and experiment. The simulated syngas compositions are acceptable compared with experimental data by the root mean square error (RMSE) method. In principle, the WGS and methane reforming process are kinetically restricted; larger plants have longer residence times of gases and solids within the furnace, contributing to a syngas that is closer to the final equilibrium result. The RMSE for $\mathrm{H}_{2}, \mathrm{CO}, \mathrm{CO}_{2}$, and $\mathrm{CH}_{4}$ are observed to be $0.025,0.43,0.33$, and 0.6 , respectively. However, simulation results obtained from this current study revealed no major difference from the previous study [53].

\subsection{Effect of Gasifier Temperature on Hydrogen Yield and System Performance}

The hydrogen production depends on gasifier temperature; Figure 5 shows that as the temperature rises from 650 to $750{ }^{\circ} \mathrm{C}$, the hydrogen generation increases from 9594.1 to $10,970.6 \mathrm{~kg} / \mathrm{h}$, reflecting that the higher temperature is favorable for higher hydrogen yield. The key reason for increment in hydrogen yield is because of hydro-carbon reforming reactions (Equations (6) and (7)), methane reforming reaction (Equation (4)), and WGS reaction (Equation (5)) at elevated temperatures, resulting in a lower fraction of $\mathrm{CO}$ and $\mathrm{CH}_{4}$. The result matched the previous findings $[57,58]$. In addition, the high temperature promotes tar cracking and endothermic reaction, which is advantageous in producing more $\mathrm{H}_{2}[58,59]$. High temperature also enables $\mathrm{CO}_{2}$ production due to enhancement of biomass pyrolysis and water gas shift reaction. The $\mathrm{CaO}$ effectively absorbs the $\mathrm{CO}_{2}$ produced (carbonation process (Equation (8)), which is enhanced by moving equilibrium of $\mathrm{CaO}$ carbonation towards forward direction, a function of temperature [53]. The system efficiency is increasing first and then decreasing, but the reduction in efficiency is not considerable. The reason is that with the increase in hydrogen production and separation by PSA, the remaining syngas quality decreases, resulting in decrease in the syngas heat output, which in turns produces less electricity by the combined cycle. The effect of temperature on calcium looping gasification limits hydrogen production; thus, it significantly affects the system efficiency. 


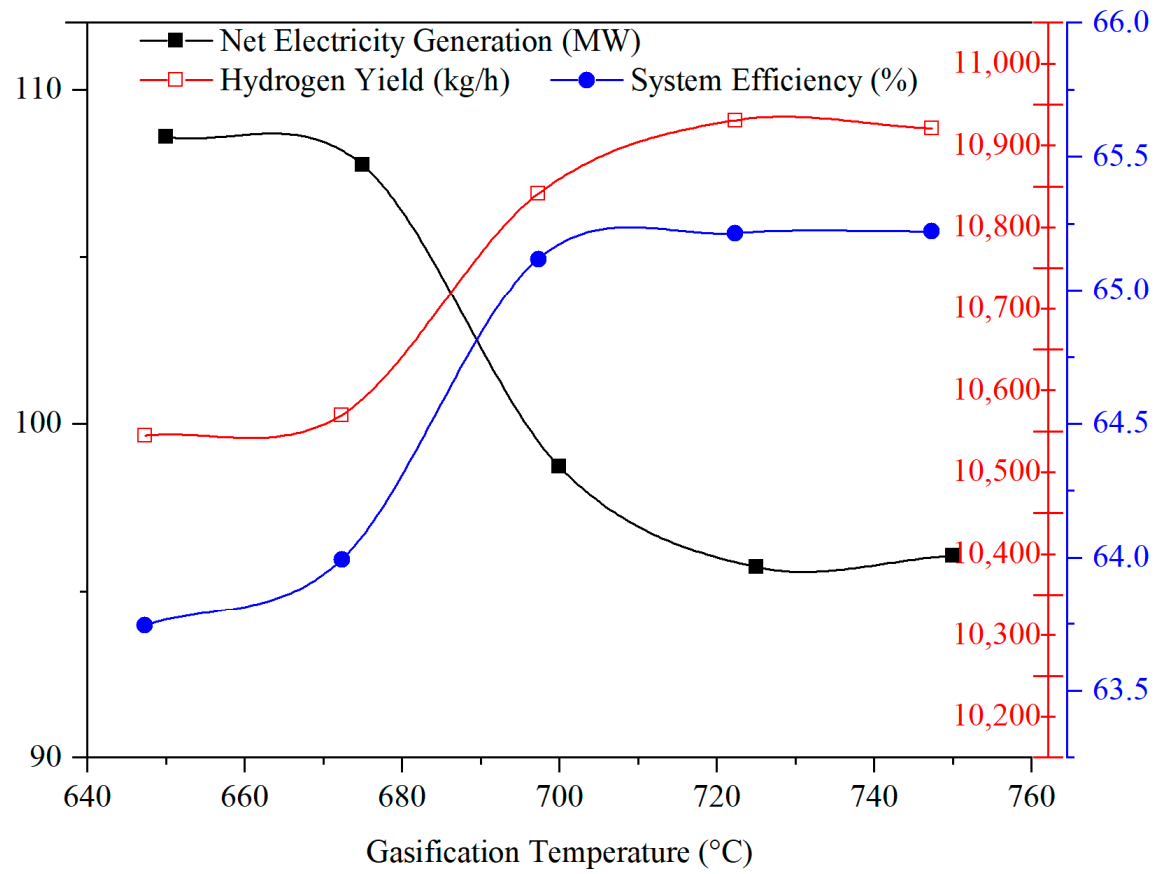

Figure 5. The effect of gasifier temperature on hydrogen yield, net electricity generation, and system performance for CLGCC-H system.

Now we turn to the CLGCC system and analyze the effect of gasifier temperature on electricity generation. This situation is depicted in Figure 6, fairly reflecting an analogous behavior to that of the CLGCC-H system. One observes an increase in electricity generation as temperature increases for the temperature range $650-750{ }^{\circ} \mathrm{C}$, reaching its maximum of $391.96 \mathrm{MWe}$ corresponding to $700{ }^{\circ} \mathrm{C}$. Beyond this point, a gradual decrease is witnessed, and eventually settles to $391 \mathrm{MWe}$ at $750^{\circ} \mathrm{C}$. The underlying processes involves an increment in syngas quality with the inclusion of hydrogen content and hence an improved electricity generation vis-a-vis temperature. However, figuratively speaking, the corresponding values for electricity generation and system efficiency turn out to be low compared with the CLGCC-H system.

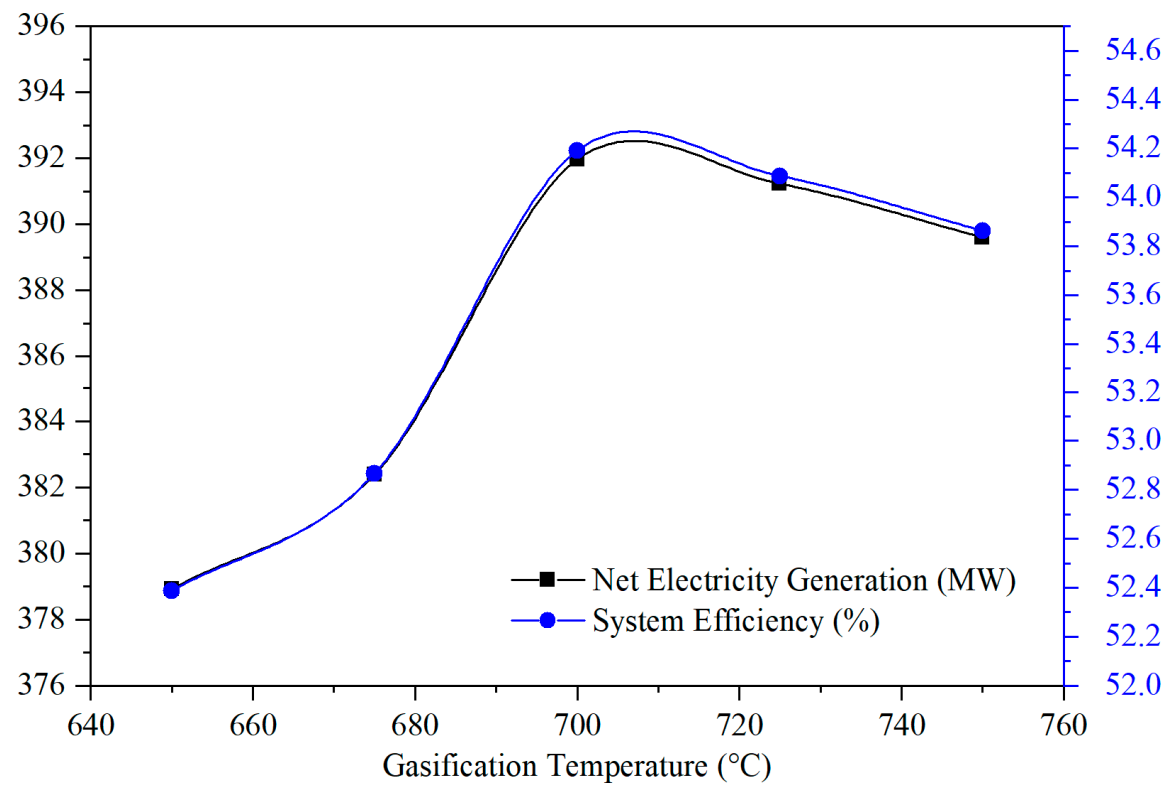

Figure 6. The effect of gasifier temperature on net electricity generation and system performance for CLGCC system. 


\subsection{Effect of Gasifier Pressure on Hydrogen Yield and System Performance}

Another critical variable in the CLG process is pressure. Pressurized CLG process has some advantages over traditional atmospheric CLG process, e.g., increase in the rate of char gasification $[53,60]$, the power reduction for compressing syngas to high pressure before using a gas turbine [61], and improvement in heat and mass transfer in fluidized bed [62].

Figure 7 shows that from 1 to 6 bar pressure, the hydrogen yield and other product gases remain constant; however, after 6 bar pressure, the hydrogen yield increases first and then decreases. This trend is because from 1 to 6 bar pressure carbonation reaction (Equation (8)) cannot be realized at calculated temperature $\left(700^{\circ} \mathrm{C}\right)$, after 6 bar pressure, the $\mathrm{CO}_{2}$ absorption started and gradually increases with the increase of pressure. The partial pressure of $\mathrm{CO}_{2}$ decreases due to its adsorption, which promotes water gas shift reaction to convert $\mathrm{CO}$ and $\mathrm{H}_{2} \mathrm{O}$ in the gas phase to produce more $\mathrm{H}_{2}$ accordingly. Further, it is observed from Figure 7 that at approximately 12 bar pressure, the hydrogen yield achieved a maximum value of $11,082.1 \mathrm{~kg} / \mathrm{h}$. In addition, at higher pressure (above $12 \mathrm{bar}$ ), the steam methane reforming reaction started to work in a reverse direction to produce $\mathrm{CH}_{4}$ and $\mathrm{H}_{2} \mathrm{O}$, which in turn caused reduction in hydrogen yield. After 25 bar pressure, the results of the current study cannot be observed, and no study found in the literature reported any results above this pressure. However, at high-pressure, the $\mathrm{CH}_{4}$ mole fraction in the gas phase increases with the favor of reverse steam methane reforming reaction (Equation (4)). Enhanced reverse reaction (Equation (4)) delivers more energy to maintain the gasifier temperature, increases carbon conversion and cold gas efficiency continuously under pressured conditions, and requires less char to be burned. The same aforementioned phenomena are also observed in the CLGCC system. Unlike the temperature case, the impact of gasifier pressure has a radically distinguished character for both electricity generation and system efficiency, depending upon whether one considers the CLGCC or CLGCC-H system. As shown in Figure 8, electricity generation shows an increment for the pressure range 6-12 bar, reaching its peak and eventually decreasing to its minimum of 365 MWe at 20 bar pressure. Compared to the CLGCC-H system, considerable increase is reported due to improved syngas quality. However, concerning system efficiency, one notes no considerable difference in terms of overall behavior, though the numbers differ. We can deduce from the results that gasification with high-pressure operation is a preferable alternative for energy conversion. Still, it may not be a suitable option for hydrogen production without providing costly and sophisticated downstream reformers. After a thorough assessment, it is concluded that the optimum pressure should be set between 12-20 bars.

\subsection{System Energy Conversion Efficiency}

The dual fluidized bed $\left(\mathrm{CaO}-\mathrm{CaCO}_{3}\right.$ recirculation) is a crucial part of calcium looping gasification for hydrogen and electricity production. For calcination and carbonation, it is necessary to operate the gasifier and combustor at appropriate temperature and pressure to fulfil thermodynamic effectiveness. The gasifier temperature is controlled at $700{ }^{\circ} \mathrm{C}$ and the combustor at $1000{ }^{\circ} \mathrm{C}$ for 12 bar operating pressure. The experiments set the steam $/ \mathrm{C}$ ratio and $\mathrm{CaO} / \mathrm{C}$ ratio as 2 and 1 for optimized hydrogen yield [53,63]. The biomass treatment capacity of the CLGCC-H and the CLGCC power plant is $131.16 \mathrm{t} / \mathrm{h}$. Table 5 compares the thermodynamic performance of the CLGCC-H and CLGCC power plants. In the CLGCC-H system, clean syngas from selexol is fed to PSA for hydrogen separation, which separates $10,284.57 \mathrm{~kg} / \mathrm{h}$ of hydrogen. After hydrogen separation, the remaining syngas is combusted in GT to produce electrical power. In addition, the waste heat from different parts of the plant and flue gases produced by the GT enters into the HRSG to produce steam for power generation through the Rankine cycle. The CLGCC-H plant can realize the coproduction of hydrogen energy of $342.54 \mathrm{MW}$ and the electricity of $147.55 \mathrm{MWe}$. The system energy and exergy efficiency of the CLGCC-H system can reach $64.75 \%$ and $60.79 \%$, which is $10.56 \%$ and $9.57 \%$ higher than the CLGCC system. From the perspective of power 
generation of the CLGCC system, the output of GT is $317.76 \mathrm{MWe}$, and the ST the total power generation is $95.17 \mathrm{MWe}$, with a net power output of $391.96 \mathrm{MWe}$.

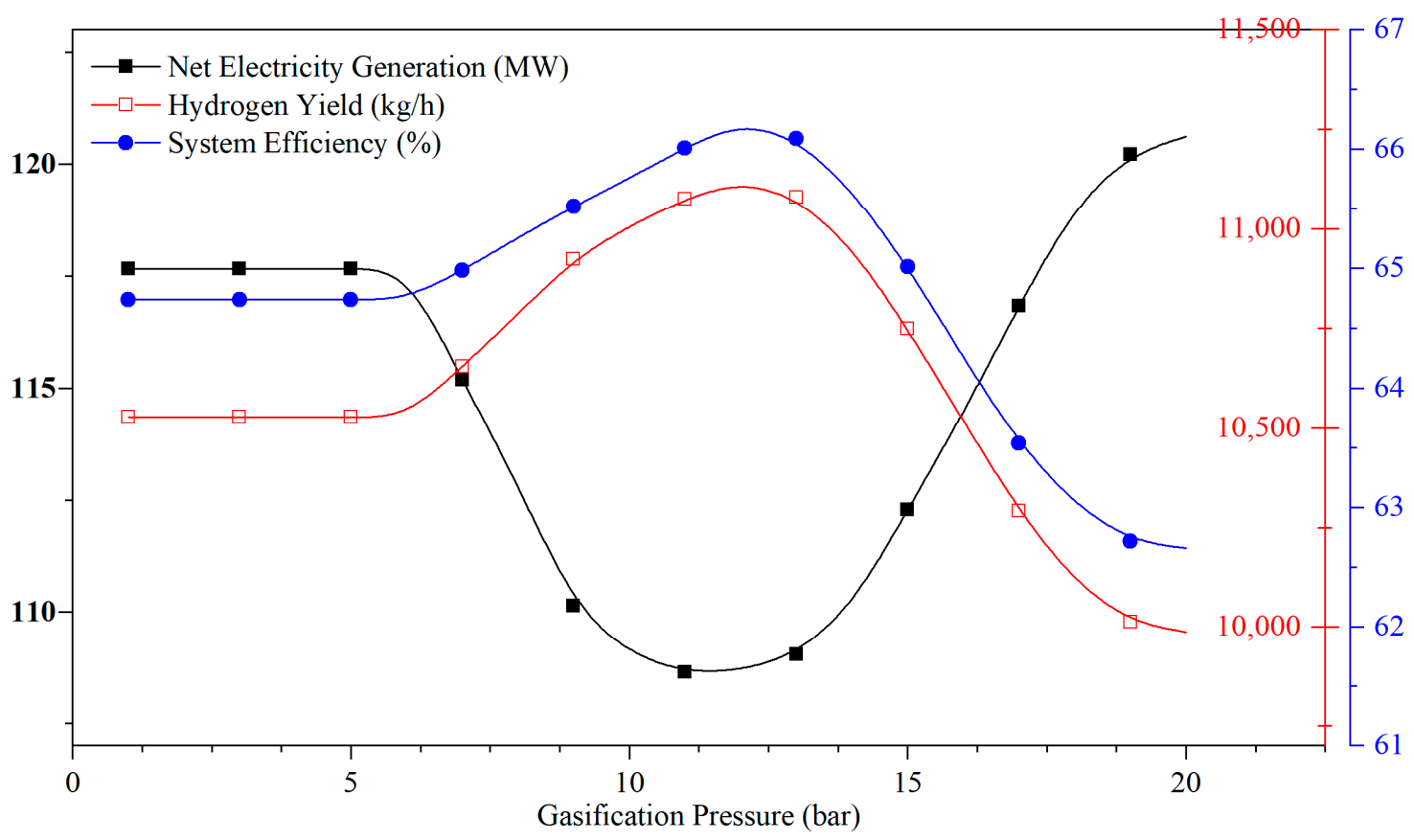

Figure 7. The effect of gasifier pressure on hydrogen yield, net electricity generation, and system performance for CLGCC-H system.

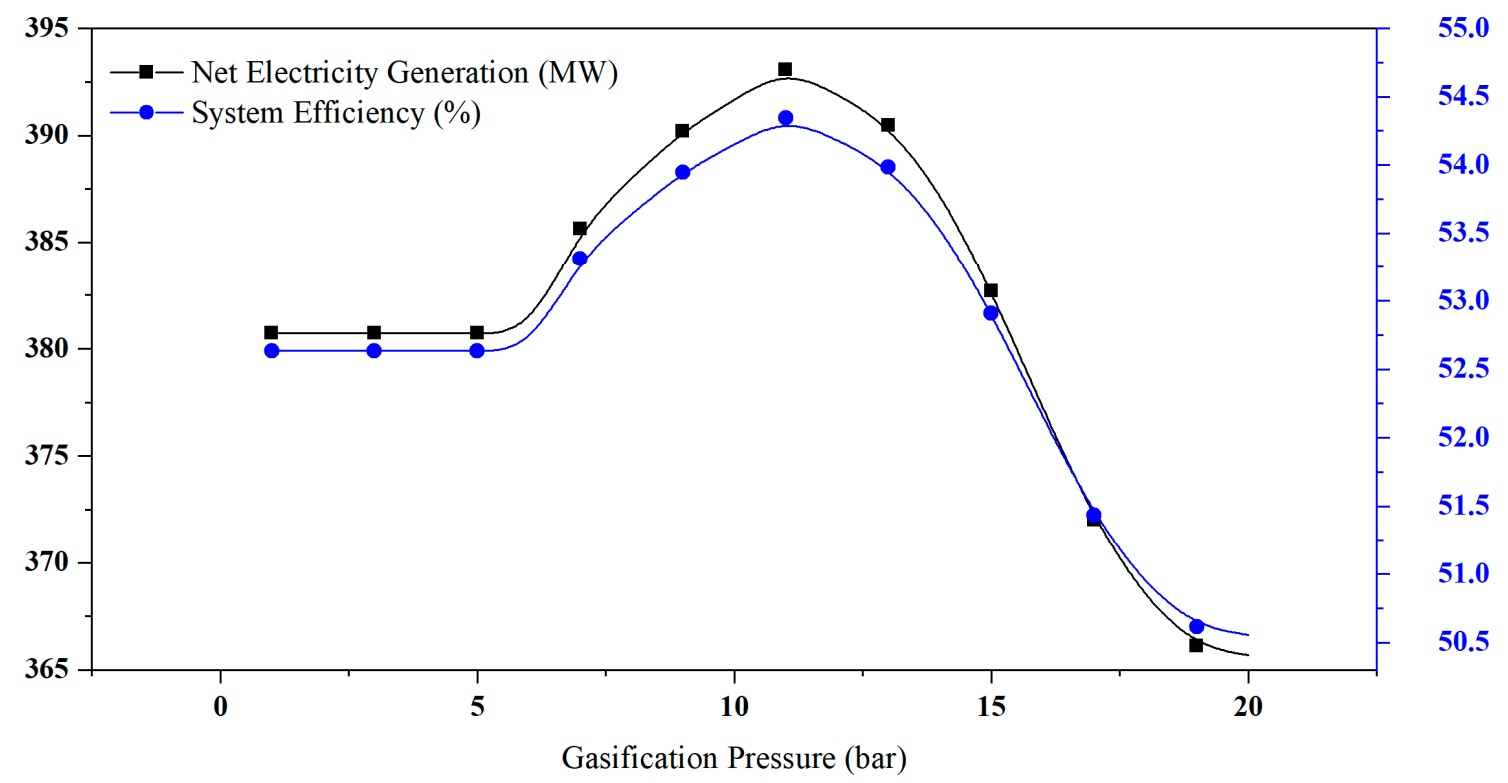

Figure 8. The effect of gasifier pressure on net electricity generation, and system performance for CLGCC system. 
Table 5. Thermodynamic comparisons of CLGCC and CLGCC-H with biomass and coal.

\begin{tabular}{|c|c|c|c|}
\hline Facility & Parameter & CLGCC-H & CLGCC \\
\hline \multicolumn{4}{|l|}{ Fuel input } \\
\hline & Input pulverized biomass (kg/s) & 36.43 & 36.43 \\
\hline & $\mathrm{LHV}(\mathrm{MJ} / \mathrm{kg})$ & 19.85 & 19.85 \\
\hline & Thermal input (MW) & 723.31 & 723.31 \\
\hline \multicolumn{4}{|l|}{ Gasifier } \\
\hline & Outlet pressure (bar) & 12.00 & 12.00 \\
\hline & Outlet temperature $\left({ }^{\circ} \mathrm{C}\right)$ & 700.00 & 700.00 \\
\hline & Steam $(\mathrm{kg} / \mathrm{s})$ & 26.25 & 26.25 \\
\hline & Syngas mass flow $(\mathrm{kg} / \mathrm{s})$ & 23.21 & 23.21 \\
\hline & Syngas LHV (MJ/kg) & 24.26 & 24.26 \\
\hline & Thermal output (MW) & 562.98 & 562.98 \\
\hline \multicolumn{4}{|l|}{ Combustor } \\
\hline & Outlet pressure (bar) & 12 & 12 \\
\hline & Outlet temperature $\left({ }^{\circ} \mathrm{C}\right)$ & 1000 & 1000 \\
\hline & Oxygen mass flow $(\mathrm{kg} / \mathrm{s})$ & 14.91 & 14.91 \\
\hline & $\mathrm{CO}_{2}$-rich mass flow $(\mathrm{kg} / \mathrm{s})$ & 53.79 & 53.79 \\
\hline \multicolumn{4}{|c|}{ Scrubber column } \\
\hline & Pressure syngas (bar) & 11.7 & 11.7 \\
\hline & Outlet temperature syngas $\left({ }^{\circ} \mathrm{C}\right)$ & 45 & 45 \\
\hline \multicolumn{4}{|l|}{$\mathrm{H}_{2} \mathrm{~S}$ absorber } \\
\hline & Outlet temperature syngas $\left({ }^{\circ} \mathrm{C}\right)$ & 11.92 & 11.92 \\
\hline & Mass flow syngas $(\mathrm{kg} / \mathrm{s})$ & 12.8 & 12.8 \\
\hline & Syngas LHV (MJ/kg) & 41.13 & 41.13 \\
\hline \multicolumn{4}{|l|}{ PSA } \\
\hline & Hydrogen (kg/h) & $10,284.57$ & - \\
\hline & Hydrogen LHV (MJ/kg) & 119.90 & - \\
\hline & Hydrogen energy output (MW) & 342.54 & - \\
\hline \multicolumn{4}{|l|}{ Power block } \\
\hline & Air compressor discharge (bar) & 20 & 20 \\
\hline & Combustion chamber (bar) & 19.02 & 19.02 \\
\hline & Gas turbine inlet temperature $\left({ }^{\circ} \mathrm{C}\right)$ & 1502 & 1502 \\
\hline & Gas turbine pressure ratio & 18.65 & 18.65 \\
\hline & Gas turbine power output (MWe) & 107.82 & 317.76 \\
\hline & Steam cycle power output (MWe) & 39.73 & 95.17 \\
\hline \multicolumn{4}{|l|}{ Power output } \\
\hline & Gross power output (MW) & 490.09 & 412.93 \\
\hline & Auxiliary load (MW) & 21.76 & 20.97 \\
\hline & Net power output (MW) & 468.33 & 391.96 \\
\hline & Net efficiency (\%) & 64.75 & 54.19 \\
\hline & Exergy efficiency (\%) & 60.79 & 51.22 \\
\hline & $\eta_{\text {CCS }}(\%)$ & 83.12 & 83.12 \\
\hline
\end{tabular}

\subsection{Economic Analyses}

This section reports an economic analysis of the CLGCC-H system and compares it against the CLGCC system. Before the economic analysis, the baseline data for each part are presented in Tables 4 and 6, which present the assumptions for total production cost. In addition, Table 7 shows the baseline economic data, the economic comparison of the CLGCC-H and the CLGCC systems is carried out, as shown in Table 8.

Table 8 shows that the FCI of the CLGCC-H system is approximately USD $689.66 \mathrm{mil}-$ lion, and the FCI of the CLGCC is USD 770.99 million, which is about USD 81.32 million higher than that of the CLGCC-H system. This is due to the higher investment in power island and heat recovery during electricity production. Low investment is required for the CLGCC-H system power island, as most of the hydrogen from $\mathrm{H}_{2}$-rich syngas is separated through PSA for the downstream process (i.e., fuel cell, transport fuel, or oil upgradation) and less syngas is available for electricity production. According to the economic calculations, the production cost of $\mathrm{H}_{2}$ is calculated to be $2.37 \mathrm{USD} / \mathrm{kg}$; with this hydrogen price the IRR of the CLGCC-H system with dual products (hydrogen and electricity) reaches $17.43 \%$, while that of the CLGCC system is only $11.45 \%$. The CLGCC-H system payback period is 7.35 years, which is 2.64 years less than the CLGCC system. Owing to high IRR and short payback period, the CLGCC-H system is deemed to be promising. 
Table 6. Assumptions of the total production cost.

\begin{tabular}{ll}
\hline Component & Basis \\
\hline (A) Raw material & Pine sawdust 65.12 USD/t \\
(B) Utilities & Water 0.7 USD/t; electricity 0.07 USD $/ \mathrm{kWh}$ \\
(C) Operating and maintenance & \\
(1) Operating labor + welfare & 200 laborers $(45,000 \mathrm{USD} /$ laborer $/$ year $)+10 \%$ \\
(2) Direct supervisory and clerical labor & operating labor \\
(3) Maintenance and repairs & $20 \%$ of operating labor \\
(4) Operating supplies & $2 \%$ of fixed capital investment \\
(5) Laboratory charge & $0.7 \%$ of fixed capital investment \\
(D) Depreciation & $15 \%$ of operating labor \\
(E) Interest and surcharge & Salvage value: $4 \%$, life period: 30 years \\
(F) Plant overhead cost & According the landing schedule \\
(G) Administrative cost & $60 \%$ of $(1)+(2)+(3)$ \\
(H) Distribution and selling cost & $2 \%$ of total production cost \\
(I) Total production cost & $2 \%$ of total production cost \\
\hline & $(A)+(B)+(C)+(D)+(E)+(F)+(G)+(H)$ \\
\hline
\end{tabular}

Table 7. The basic economic assumptions.

\begin{tabular}{llll}
\hline Items & Value & Price & Value \\
\hline Discount rate & $8 \%$ & Biomass & $65.12 \mathrm{USD} / \mathrm{t}$ \\
Plant life & 30 years & Water & $0.76 \mathrm{USD} / \mathrm{t}$ \\
Yearly running time & $8000 \mathrm{~h}$ & Electricity & $0.07 \mathrm{USD} / \mathrm{kWh}$ \\
Establishment period & 3 years & Sulfur & $115 \mathrm{USD} / \mathrm{t}$ \\
Tax & $25 \%$ & Limestone & $19.97 \mathrm{USD} / \mathrm{t}$ \\
Interest & $7.53 \%$ & & \\
\hline
\end{tabular}

\subsection{Sensitivity Analysis}

The IRR is a cost analysis method for determining the profitability of a process. The IRR is a discount rate that makes the $\mathrm{H}_{2}$ processing plant's net present value (NPV) zero. This might bring the plant's cash input and outflow into balance: the higher the IRR discount rate, the lower the NPV and longer the payback period. The plant will be more successful if the IRR discount rate is lower, the NPV is larger, and the payback period is shorter [64]. Sensitivity to IRR is an important factor in determining the annual growth rate of plant investment, and it emphasizes the payback period.

Referring to the economic sensitivity analysis of the power plants with CCS [4,47], a sensitivity analysis was performed by varying main economic parameters leads, e.g., biomass price, electricity price, hydrogen price yearly running hours, and capital expenditure (fixed capital cost). The economic parameters are identified by variation from $-50 \%$ to $50 \%$.

Figure 9 shows the economic sensitivity of the CLGCC-H. It is observed that the IRR increases up to $25.14 \%$ corresponding to the $50 \%$ increase in hydrogen price. On the other hand, the IRR decreases $8.87 \%$ when the hydrogen price decreases by $50 \%$. Similarly, the IRR can increase up to $23.83 \%$ when the fixed capital cost decreases to $50 \%$. Apparently, the IRR is sensitive to the variation of hydrogen selling price and fixed capital investment. The other parameters such as biomass price and electricity price have a sensitivity effect on the IRR, but the degree of sensitivity is unlike the hydrogen selling price and fixed capital cost.

Similarly, Figure 10 shows the sensitivity analysis for the CLGCC system. The main product of the CLGCC system is only electricity, so the IRR increases up to $18.98 \%$ when the electricity selling price increases by $50 \%$. In contrast, it could be down to $2.29 \%$, while the price of electricity decreases to 50\%. Similarly, the IRR can increase up to $19.85 \%$, corresponding to a $50 \%$ decrease in fixed capital cost. The hydrogen selling price has no effect at all on the IRR with $\pm 50 \%$ variation in hydrogen selling price. The IRR is slightly affected by the variation in biomass price.

From Figures 9 and 10, it can be observed that the yearly running time has a significant effect on the IRR. It could be down to $14.63 \%$ and $6.21 \%$ for the CLGCC-H and CLGCC, as the yearly running time decreases to $50 \%$. Figure 11 shows sensitivity analysis over the 
plant life (15 to 30 years). The IRR decreases to $15.49 \%$ and $8.54 \%$ for the CLGCC-H and CLGCC corresponding to 15 years decrease in the plant life.

Table 8. Economic comparison of CLGCC and CLGCC-H with biomass.

\begin{tabular}{|c|c|c|}
\hline Items & CLGCC-H & CLGCC \\
\hline \multicolumn{3}{|l|}{ Fuel and material consumption $\left(10^{6} \mathrm{t} / \mathrm{y}\right)$} \\
\hline Biomass & 1.05 & 1.05 \\
\hline Water & 1.24 & 1.24 \\
\hline Limestone $(\mathrm{t} / \mathrm{y})$ & 6299 & 6299 \\
\hline \multicolumn{3}{|l|}{ Product } \\
\hline Sulfur $(t / y)$ & 5681.83 & 5681.83 \\
\hline Hydrogen (99.99 vol\% purity) $(\mathrm{kg} / \mathrm{y})$ & $8.74 \times 10^{7}$ & - \\
\hline Electricity $(\mathrm{kWh} / \mathrm{y})$ & $1.18 \times 10^{9}$ & $3.30 \times 10^{9}$ \\
\hline $\mathrm{CO}_{2}$ & $1.55 \times 10^{6}$ & $1.55 \times 10^{6}$ \\
\hline \multicolumn{3}{|l|}{ Capital cost $\left(10^{6}\right)$} \\
\hline Fuel preparation & 29 & 29 \\
\hline $\begin{array}{l}\text { DFB (including gasifier, combustor, } \\
\text { cyclones, fans, other facilities) }\end{array}$ & 413.18 & 413.18 \\
\hline Air separation unit (ASU) & 73.32 & 73.32 \\
\hline Selexol unit & 15.76 & 15.76 \\
\hline $\mathrm{H}_{2}$ PSA unit & 21.14 & - \\
\hline Claus/SCOT unit & 10.92 & 10.92 \\
\hline Heat exchangers & 26.03 & 30.38 \\
\hline Power island $(\mathrm{GT}+\mathrm{ST})$ & 89.97 & 188.08 \\
\hline $\mathrm{CO}_{2}$ compression & 10.35 & 10.35 \\
\hline Fixed capital cost & 689.66 & 770.99 \\
\hline Working capital & 137.93 & 154.20 \\
\hline Total capital investment & 827.60 & 925.18 \\
\hline Raw material & 68.46 & 68.46 \\
\hline Utilities & 15.87 & 15.55 \\
\hline Operating and maintenance & 30.86 & 33.09 \\
\hline Depreciation & 23.29 & 26.07 \\
\hline Intrest and surcharges & 47.24 & 54.08 \\
\hline Plant overhead cost & 14.81 & 15.80 \\
\hline Administrative cost & 3.26 & 3.38 \\
\hline Distribution and selling cost & 3.26 & 3.38 \\
\hline Total production cost & 207.05 & 219.80 \\
\hline Hydrogen production cost ${ }^{\mathrm{a}}$ (USD/kg) & 2.37 & - \\
\hline Revenue $^{b}\left(10^{6}\right.$ USD] & 290.56 & 231.74 \\
\hline Profit before tax ${ }^{c}\left(10^{6}\right.$ USD) & 83.51 & 11.94 \\
\hline Tax rate & $25 \%$ & $25 \%$ \\
\hline Profit after tax $\left(10^{6}\right.$ USD/year $)$ & 62.63 & 8.96 \\
\hline $\operatorname{IRR}(\%)$ & 17.43 & 11.45 \\
\hline NPV $\left(10^{6}\right.$ USD $)$ & 677.67 & 267.42 \\
\hline Payback Period (y) & 7.35 & 9.99 \\
\hline
\end{tabular}

a Hydrogen production cost $=$ Total production cost $/ \mathrm{H}_{2}$ yield. ${ }^{\mathrm{b}}$ Revenue $=$ Hydrogen price $\times$ Hydrogen yield + Electricity price $\times$ Electricity production + Sulfur price $\times$ Sulfur yield. ${ }^{c}$ Profit before tax $=$ Revenue - Total production cost.

\subsection{Uncertainty Sources of Sensitivity Analysis}

According to Cristóbal et al. [65], the following uncertainty sources must be addressed for sensitivity analysis: method of cost calculation, revenue, utility cost, process variables, feedstock price, and transportation. Among the different causes of uncertainty in sensitivity analysis, the method for low TRL technologies cost estimating shows a $\pm 50 \%$ deviation, as a result of failures in inflation projection or cost growth. It is due to a highly complex process's unexpected events and technology that have yet to be verified. The proposed project's revenue is primarily determined by the end product's composition, quality, quantity, and selling price, which are determined by its demand in the global market. The cost of utilities varies depending on the process type. Typically, hydrogen, electricity, and feedstock prices are considered basic factors that might fluctuate due to various circumstances, including environmental safety concerns, unpredictable weather conditions, geopolitical situations, and government taxes. In general, the results of laboratory experiments are utilized to scale up processes to obtain the same efficiency. However, in other circumstances, the process 
variable costs are dependent on the size of scale-up plants, which has an indirect impact on revenue. The process profitability is also determined by the amount of transportation and feedstock availability.

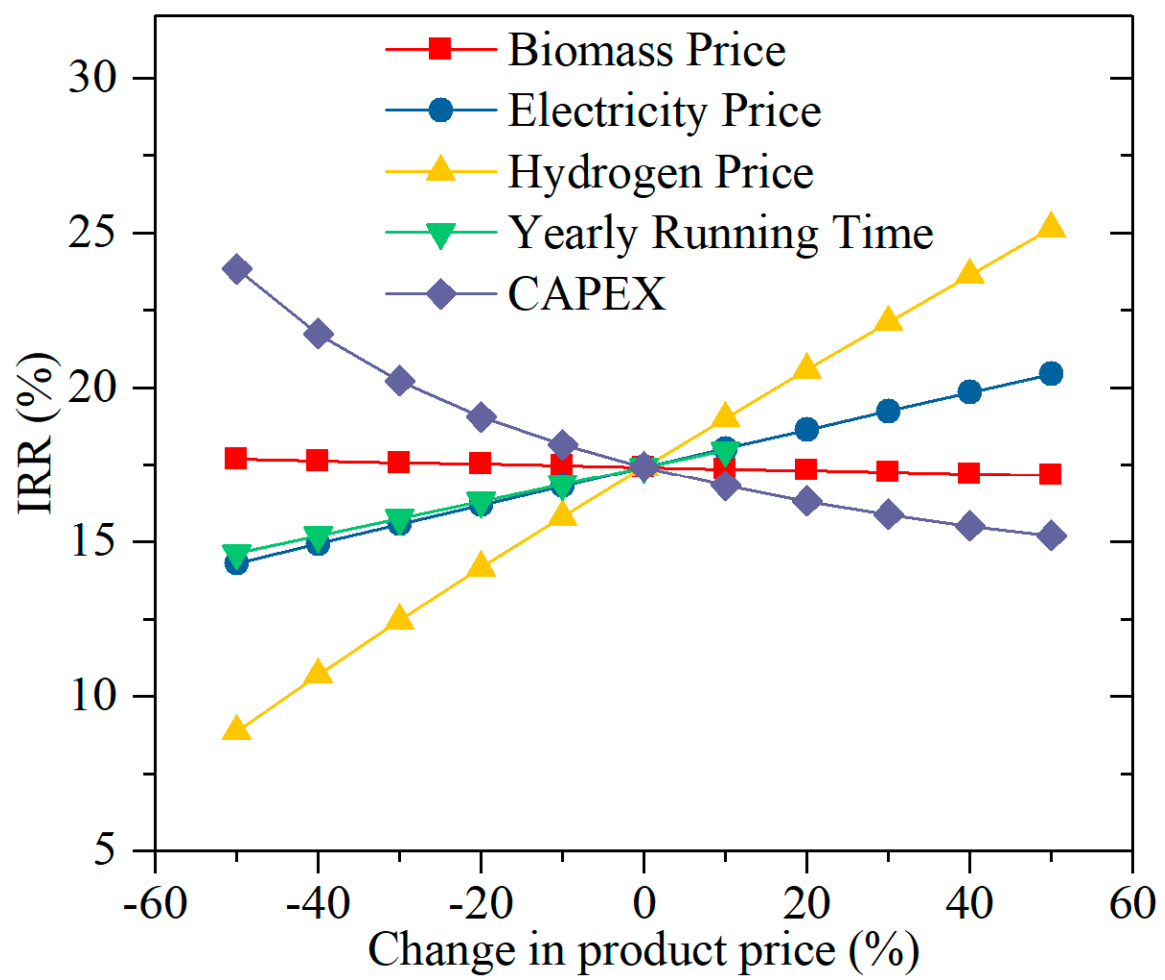

Figure 9. Influence of product price on IRR for the CLGCC-H.

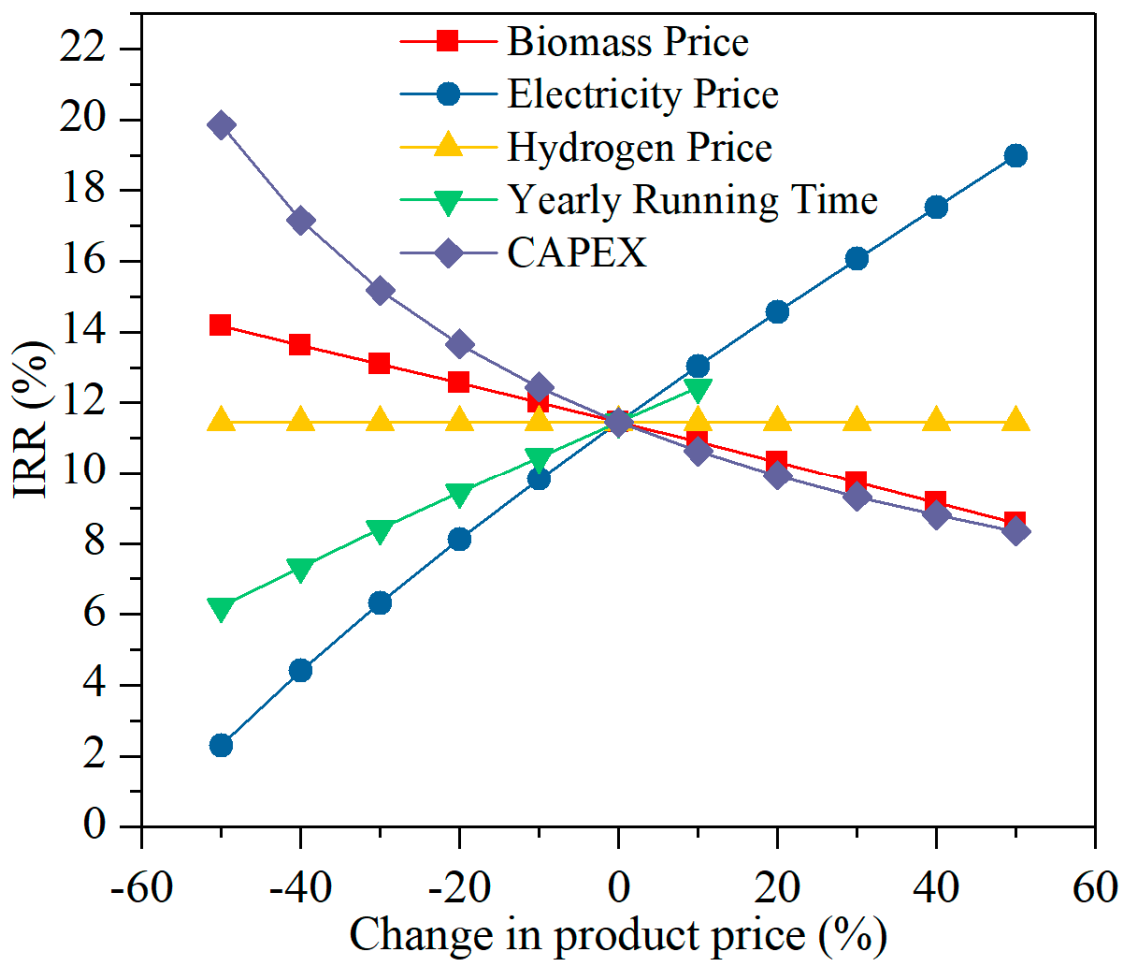

Figure 10. Influence of product price on IRR for the CLGCC. 


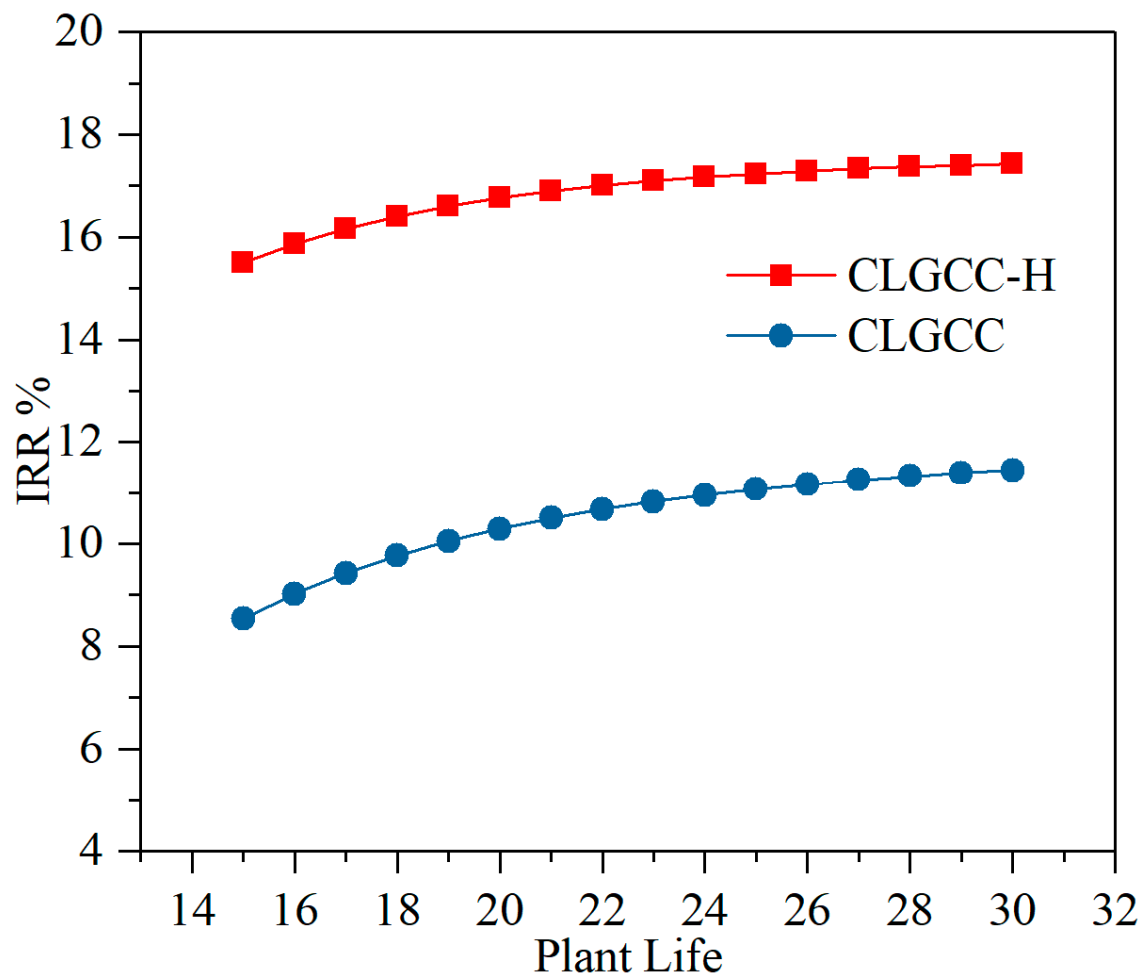

Figure 11. Influence of plant life on IRR for CLGCC-H and CLGCC.

\section{Conclusions}

In summary, we proposed and carried out an in-depth techno-economic analysis of a novel energy conversion system that is based on calcium looping gasification of biomass for hydrogen and electricity production. The CLGCC-H system is investigated by employing process simulation using Aspen Plus simulation and compared to that of the CLGCC. A comprehensive comparison of the thermodynamic and economic performance of the CLGCC-H and the CLGCC systems is conducted.

We explicitly demonstrated, based on a thermodynamic and economic analyses, that CLGCC-H's system energy and exergy efficiency is higher than that of the CLGCC system. Concerning system energy, the CLGCC-H system's peak system energy stood at $64.75 \%$, which is approximately $10.56 \%$ higher than the CLGCC system. Moreover, the exergy efficiency of the CLGCC-H system attains its peak at around $60.79 \%$, which is roughly 9.57\% higher than the CLGCC system. For economic analysis of the CLGCC-H system, the IRR was reported at $17.43 \%$ with a payback period of 7.35 years, while the same for the CLGCC system are $11.45 \%$ and 9.99 years, respectively. Based on these thermodynamic and economic analyses outcomes, we conclude that the CLGCC-H could potentially hold a great market value.

Author Contributions: Conceptualization, Q.W. and A.R.S.; methodology, A.R.S.; software, A.R.S.; validation, A.R.S., Y.F. and Z.L.; formal analysis, Z.S.; investigation, J.C.; resources, Q.W.; data curation, S.K.; writing—original draft preparation, A.R.S.; writing-review and editing, L.H.; visualization, Z.S.; supervision, Q.W.; project administration, Q.W.; funding acquisition, Q.W. All authors have read and agreed to the published version of the manuscript.

Funding: We would like to express our gratitude for the financial assistance provided by China's National Key R\&D Program (2019YFE100100-05).

Institutional Review Board Statement: Not applicable.

Informed Consent Statement: Not applicable.

Conflicts of Interest: The authors declare no conflict of interest. 


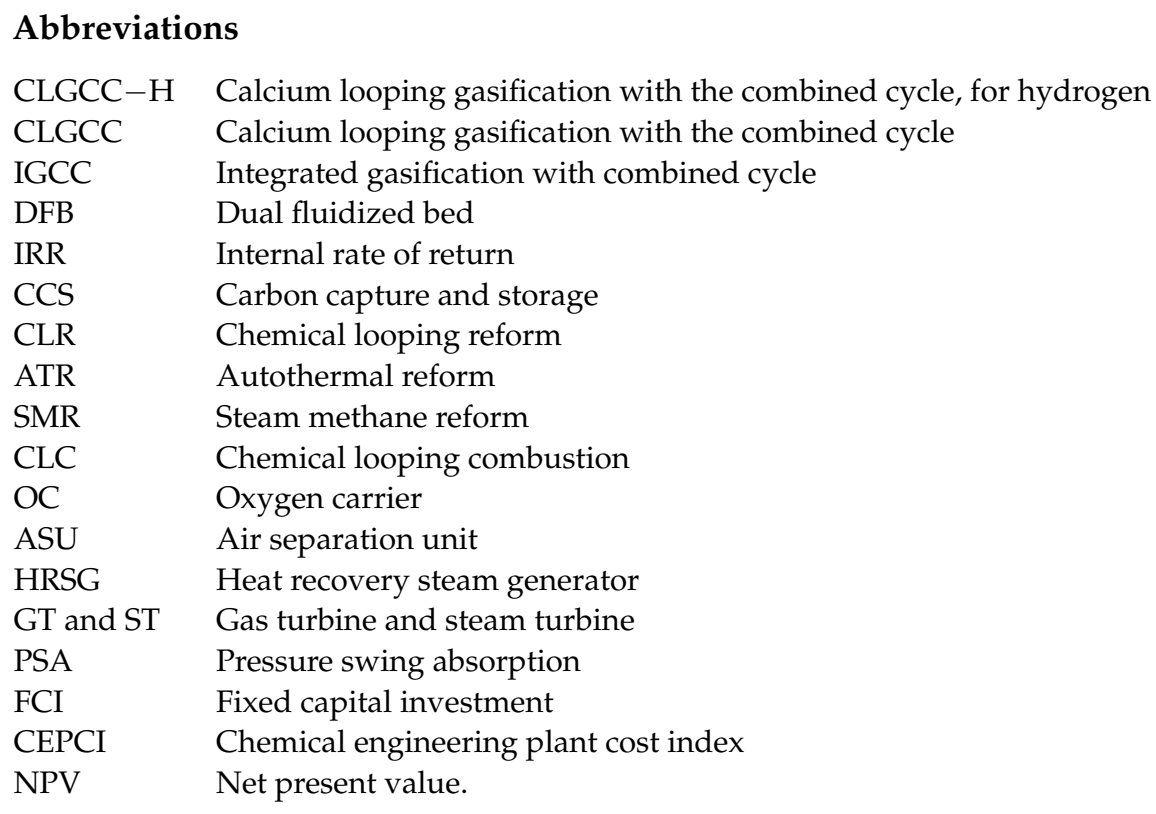

\section{Nomenclature}

$\begin{array}{ll}\eta \text { and } \varepsilon & \text { System efficiency and exergy } \\ \mathrm{E}_{\text {net }} & \text { Net power generation (MW) } \\ \mathrm{E}_{\mathrm{ST}} & \text { Power generation of steam turbines (MW) } \\ \mathrm{E}_{\mathrm{GT}} & \text { Power generation of gas turbines (MW) } \\ \mathrm{E}_{\mathrm{AUX}} & \text { Power consumption of auxiliary equipment (MW) } \\ \mathrm{LHV}_{\text {biomass }} & \text { Lower calorific value of biomass (MW) } \\ \mathrm{FCI} & \text { Fixed capital investment }\left(10^{6} \text { USD) }\right. \\ \mathrm{Si} & \text { Production capacity index } \\ \mathrm{Ct} & \text { Cash flows of the year } \mathrm{t}\left(10^{6} \text { USD) }\right. \\ \mathrm{CRF} & \text { Average annual investment ratio } \\ \mathrm{OAM} & \text { Annual operation and management cost ratio } \\ \mathrm{Cp} & \text { Annual income of products }\left(10^{6} \mathrm{USD}\right) \\ \mathrm{CM} & \text { Material cost }\left(10^{6} \text { USD) }\right. \\ \mathrm{CF}_{\mathrm{F}} & \text { Fuel cost }\left(10^{6} \text { USD) }\right.\end{array}$

\section{References}

1. Yan, Y.; Manovic, V.; Anthony, E.J.; Clough, P.T. Techno-economic analysis of low-carbon hydrogen production by sorption enhanced steam methane reforming (SE-SMR) processes. Energy Convers. Manag. 2020, 226, 113530. [CrossRef]

2. Yan, Y.; Thanganadar, D.; Clough, P.T.; Mukherjee, S.; Patchigolla, K.; Manovic, V.; Anthony, E.J. Process simulations of blue hydrogen production by upgraded sorption enhanced steam methane reforming (SE-SMR) processes. Energy Convers. Manag. 2020, 222, 113144. [CrossRef]

3. IEA. The Future of Hydrogen, IEA, Paris. 2019. Available online: https://www.iea.org/reports/the-future-of-hydrogen (accessed on 10 July 2021).

4. Esmaili, E.; Mostafavi, E.; Mahinpey, N. Economic assessment of integrated coal gasification combined cycle with sorbent CO2 capture. Appl. Energy 2016, 169, 341-352. [CrossRef]

5. Sara, H.R.; Enrico, B.; Mauro, V.; Andrea, D.C.; Vincenzo, N. Techno-Economic Analysis of Hydrogen Production Using Biomass Gasification-A Small Scale Power Plant Study. In Energy Procedia; Elsevier Ltd.: Amsterdam, The Netherlands, 2016; pp. 806-813. [CrossRef]

6. Hanley, E.S.; Deane, J.P.; Gallachóir, B.P.Ó. The role of hydrogen in low carbon energy futures-A review of existing perspectives Renew. Sustain. Energy Rev. 2018, 82, 3027-3045. [CrossRef]

7. Yukesh Kannah, R.; Kavitha, S.; Preethi; Parthiba Karthikeyan, O.; Kumar, G.; Dai-Viet, N.V.; Rajesh Banu, J. Techno-economic assessment of various hydrogen production methods-A review. Bioresour. Technol. 2021, 319, 124175. [CrossRef]

8. Capros, P.; Zazias, G.; Evangelopoulou, S.; Kannavou, M.; Fotiou, T.; Siskos, P.; De Vita, A.; Sakellaris, K. Energy-system modelling of the EU strategy towards climate-neutrality. Energy Policy 2019, 134, 110960. [CrossRef]

9. Hosseini, S.E.; Wahid, M.A. Hydrogen production from renewable and sustainable energy resources: Promising green energy carrier for clean development. Renew. Sustain. Energy Rev. 2016, 57, 850-866. [CrossRef] 
10. Li, X.Y.; Tang, B.J. Incorporating the transport sector into carbon emission trading scheme: An overview and outlook. Nat. Hazards 2017, 88, 683-698. [CrossRef]

11. Lepage, T.; Kammoun, M.; Schmetz, Q.; Richel, A. Biomass-to-hydrogen: A review of main routes production, processes evaluation and techno-economical assessment. Biomass Bioenergy 2021, 144, 105920. [CrossRef]

12. Bourne, S. The future of fuel: The future of hydrogen. Fuel Cells Bull. 2012, 2012, 12-15. [CrossRef]

13. Nazir, S.M.; Cloete, J.H.; Cloete, S.; Amini, S. Pathways to low-cost clean hydrogen production with gas switching reforming. Int. J. Hydrog. Energy 2020, 46, 20142-20158. [CrossRef]

14. Spallina, V.; Pandolfo, D.; Battistella, A.; Romano, M.C.; Van Sint Annaland, M.; Gallucci, F. Techno-economic assessment of membrane assisted fluidized bed reactors for pure $\mathrm{H}_{2}$ production with $\mathrm{CO}_{2}$ capture. Energy Convers. Manag. 2016, 120, 257-273. [CrossRef]

15. Spallina, V.; Shams, A.; Battistella, A.; Gallucci, F.; Annaland, M.V.S. Chemical Looping Technologies for $\mathrm{H}_{2}$ Production with CO, Capture: Thermodynamic Assessment and Economic Comparison. In Energy Procedia; Elsevier Ltd.: Amsterdam, The Netherlands, 2017; pp. 419-428. [CrossRef]

16. Khojasteh Salkuyeh, Y.; Saville, B.A.; MacLean, H.L. Techno-economic analysis and life cycle assessment of hydrogen production from natural gas using current and emerging technologies. Int. J. Hydrog. Energy 2017, 42, 18894-18909. [CrossRef]

17. Hafizi, A.; Rahimpour, M.R.; Hassanajili, S. Hydrogen production via chemical looping steam methane reforming process: Effect of cerium and calcium promoters on the performance of $\mathrm{Fe}_{2} \mathrm{O}_{3} / \mathrm{Al}_{2} \mathrm{O}_{3}$ oxygen carrier. Appl. Energy 2016, 165, 685-694. [CrossRef]

18. Kathe, M.V.; Empfield, A.; Na, J.; Blair, E.; Fan, L.S. Hydrogen production from natural gas using an iron-based chemical looping technology: Thermodynamic simulations and process system analysis. Appl. Energy 2016, 165, 183-201. [CrossRef]

19. Adiya, Z.I.S.G.; Dupont, V.; Mahmud, T. Steam reforming of shale gas in a packed bed reactor with and without chemical looping using nickel based oxygen carrier. Int. J. Hydrog. Energy 2018, 43, 6904-6917. [CrossRef]

20. Adiya, Z.I.S.G.; Dupont, V.; Mahmud, T. Steam reforming of shale gas with nickel and calcium looping. Fuel 2019, 237, 142-151. [CrossRef]

21. Chisalita, D.A.; Cormos, C.C. Techno-economic assessment of hydrogen production processes based on various natural gas chemical looping systems with carbon capture. Energy 2019, 181, 331-344. [CrossRef]

22. Saithong, N.; Authayanun, S.; Patcharavorachot, Y.; Arpornwichanop, A. Thermodynamic analysis of the novel chemical looping process for two-grade hydrogen production with $\mathrm{CO}_{2}$ capture. Energy Convers. Manag. 2019, 180, 325-337. [CrossRef]

23. Udomsirichakorn, J.; Salam, P.A. Review of hydrogen-enriched gas production from steam gasification of biomass: The prospect of CaO-based chemical looping gasification. Renew. Sustain. Energy Rev. 2014, 30, 565-579. [CrossRef]

24. Ii, T.A.A.; Barton, P.I. Combining coal gasification and natural gas reforming for efficient polygeneration. Fuel Process. Technol. 2010, 92, 639-655. [CrossRef]

25. Ahmed, U.; Kim, C.; Zahid, U.; Lee, C.-J.; Han, C. Integration of IGCC and methane reforming process for power generation with $\mathrm{CO}_{2}$ capture. Chem. Eng. Process Process Intensif. 2016, 111, 14-24. [CrossRef]

26. Ahmed, U.; Zahid, U.; Lee, Y. Process simulation and integration of IGCC systems for $\mathrm{H}_{2} /$ syngas/electricity generation with control on $\mathrm{CO}_{2}$ emissions. Int. J. Hydrog. Energy 2019, 44, 7137-7148. [CrossRef]

27. Cormos, C.C. Economic evaluations of coal-based combustion and gasification power plants with post-combustion $\mathrm{CO}_{2}$ capture using calcium looping cycle. Energy 2014, 78, 665-673. [CrossRef]

28. Cormos, C.C. Biomass direct chemical looping for hydrogen and power co-production: Process configuration, simulation, thermal integration and techno-economic assessment. Fuel Process. Technol. 2015, 137, 16-23. [CrossRef]

29. Jiang, P.; Berrouk, A.S.; Dara, S. Biomass Gasification Integrated with Chemical Looping System for Hydrogen and Power. Coproduction Process-Thermodynamic and Techno-Economic Assessment. Chem. Eng. Technol. 2019, 42, 1153-1168. [CrossRef]

30. Aneke, M.; Wang, M. Potential for improving the energy efficiency of cryogenic air separation unit (ASU) using binary heat recovery cycles. Appl. Therm. Eng. 2015, 81, 223-231. [CrossRef]

31. Koytsoumpa, E.I.; Atsonios, K.; Panopoulos, K.D.; Karellas, S.; Kakaras, E.; Karl, J. Modelling and assessment of acid gas removal processes in coal-derived SNG production. Appl. Therm. Eng. 2015, 74, 128-135. [CrossRef]

32. Sun, L.; Smith, R. Rectisol wash process simulation and analysis. J. Clean. Prod. 2012, 39, 321-328. [CrossRef]

33. Li, G.; Liu, Z.; Liu, F.; Weng, Y.; Ma, S.; Zhang, Y. Thermodynamic analysis and techno-economic assessment of synthetic natural gas production via ash agglomerating fluidized bed gasification using coal as fuel. Int. J. Hydrog. Energy 2020, 45, 27359-27368. [CrossRef]

34. Li, K.; Wang, Q.; Fang, M.; Shaikh, A.R.; Xie, G.; Luo, Z. Techno-economic analysis of coal staged conversion polygeneration system for power and chemicals production. Chem. Eng. Technol. 2018, 42, 73-88. [CrossRef]

35. Piéplu, A.; Saur, O.; Lavalley, J.-C.; Legendre, O.; Nédez, C. Claus Catalysis and $\mathrm{H}_{2} \mathrm{~S}$ Selective Oxidation. Catal. Rev. Sci. Eng. 1998, 40, 409-450. [CrossRef]

36. Eow, J.S. Recovery of sulfur from sour acid gas: A review of the technology. Environ. Prog. 2002, 21, 143-162. [CrossRef]

37. Riboldi, L.; Bolland, O. Evaluating Pressure Swing Adsorption as a $\mathrm{CO}_{2}$ separation technique in coal-fired power plants. Int. J. Greenh. Gas Control. 2015, 39, 1-16. [CrossRef]

38. Chen, Z.S.; Wang, L.Q. Energy and exergy analysis of gas production from biomass intermittent gasification. J. Renew. Sustain. Energy 2013, 5, 063141. [CrossRef] 
39. Seyitoglu, S.S.; Dincer, I.; Kilicarslan, A. Assessment of an IGCC based trigeneration system for power, hydrogen and synthesis fuel production. Int. J. Hydrog. Energy 2016, 41, 8168-8175. [CrossRef]

40. Sweny, J.W. Synthetic Fuel Gas Purification by the SELEXOL Process. In Proceedings of the 65. Meeting of the American Chemical Society, Dallas, TX, USA, 8 April 1973. Available online: https:/ /www.osti.gov/biblio/7346050 (accessed on 10 July 2021).

41. Green, D.W.; Perry, R.H. Perry's Chemical Engineers' Handbook, 8th ed.; McGraw-Hill Book Company: New York, NY, USA, 2008.

42. CEPCI August 2020. Available online: https:/ / www.scribd.com/document/488333013/CEPCI-august-2020 (accessed on 16 July 2021).

43. Cormos, A.M.; Cormos, C.C. Techno-economic assessment of combined hydrogen \& power co-generation with carbon capture: The case of coal gasification. Appl. Therm. Eng. 2019, 147, 29-39. [CrossRef]

44. Guo, Z.; Wang, Q.; Fang, M.; Luo, Z.; Cen, K. Thermodynamic and economic analysis of polygeneration system integrating atmospheric pressure coal pyrolysis technology with circulating fluidized bed power plant. Appl. Energy 2014, 113, 1301-1314. [CrossRef]

45. Park, C.S. Contemporary Engineering Economics, 6th ed.; Pearson Education: London, UK, 2015.

46. Ye, C.; Wang, Q.; Zheng, Y.; Li, G.; Zhang, Z.; Luo, Z. Techno-economic analysis of methanol and electricity poly-generation system based on coal partial gasification. Energy 2019, 185, 624-632. [CrossRef]

47. Shi, B.; Xu, W.; Wu, W.; Kuo, P.-C. Techno-economic analysis of oxy-fuel IGCC power plants using integrated intermittent chemical looping air separation. Energy Convers. Manag. 2019, 195, 290-301. [CrossRef]

48. Turton, R. Analysis, Synthesis, and Design of Chemical Processes, 4th ed.; Prentice Hall: Hoboken, NJ, USA, 2013.

49. Towler, G.; Sinnott, R.K. Chemical Engineering Design-Principles, Practice and Economics of Plant and Process Design, 2nd ed.; Butterworth-Heinemann: Oxford, UK, 2013.

50. Ulrich, G.D. A Guide to Chemical Engineering Process Design and Economics; John Wiley Sons: Hoboken, NJ, USA, 1984.

51. Fout, T.; Zoelle, A.; Keairns, D.; Turner, M.; Woods, M.; Kuehn, N.; Shah, V.; Chou, V.; Pinkerton, L. Cost and Performance Baseline for Fossil Energy Plants; National Energy Technology Laboratory: Pittsburgh, PA, USA; Morgantown, WV, USA, 2015.

52. Exchange Rates. US Dollar to Chinese Yuan Spot Exchange Rates for 2019. Available online: https://www.exchangerates.org.uk/ USD-CNY-spot-exchange-rates-history-2019.html (accessed on 16 July 2021).

53. Han, L.; Wang, Q.; Luo, Z.; Rong, N.; Deng, G. $\mathrm{H}_{2}$ rich gas production via pressurized fluidized bed gasification of sawdust with in situ $\mathrm{CO}_{2}$ capture. Appl. Energy 2013, 109, 36-43. [CrossRef]

54. Müller, S.; Fuchs, J.; Schmid, J.C.; Benedikt, F.; Hofbauer, H. Experimental development of sorption enhanced reforming by the use of an advanced gasification test plant. Int. J. Hydrog. Energy 2017, 42, 29694-29707. [CrossRef]

55. Udomsirichakorn, J.; Basu, P.; Abdul Salam, P.; Acharya, B. CaO-based chemical looping gasification of biomass for hydrogenenriched gas production with in situ $\mathrm{CO}_{2}$ capture and tar reduction. Fuel Process. Technol. 2014, 127, 7-12. [CrossRef]

56. Pfeifer, C.; Puchner, B.; Hofbauer, H. Comparison of dual fluidized bed steam gasification of biomass with and without selective transport of $\mathrm{CO}_{2}$. Chem. Eng. Sci. 2009, 64, 5073-5083. [CrossRef]

57. Hanaoka, T.; Yoshida, T.; Fujimoto, S.; Kamei, K.; Harada, M.; Suzuki, Y.; Hatano, H.; Yokoyama, S.Y.; Minowa, T. Hydrogen production from woody biomass by steam gasification using a $\mathrm{CO}_{2}$ sorbent. Biomass Bioenergy 2005, 28, 63-68. [CrossRef]

58. Han, L.; Wang, Q.; Yang, Y.; Yu, C.; Fang, M.; Luo, Z. Hydrogen production via CaO sorption enhanced anaerobic gasification of sawdust in a bubbling fluidized bed. Int. J. Hydrog. Energy 2011, 36, 4820-4829. [CrossRef]

59. Han, L.; Zhang, Y.; Lin, K.; Jia, X.; Zhang, H.; Zhong, Y.; Wang, Q.; Li, Z. Developing a Novel CaO-Based Sorbent for Promoted CO2 Capture and Tar Reduction. Energy Fuels 2017, 31, 5306-5317. [CrossRef]

60. Matsuoka, K.; Kajiwara, D.; Kuramoto, K.; Sharma, A.; Suzuki, Y. Factors affecting steam gasification rate of low rank coal char in a pressurized fluidized bed. Fuel Process. Technol. 2009, 90, 895-900. [CrossRef]

61. Rauch, R.; Hrbek, J.; Hofbauer, H. Biomass gasification for synthesis gas production and applications of the syngas. Wires Rev. Energy Environ. 2014, 3, 343-362. [CrossRef]

62. Shangyi, Y.; Baosheng, J.; Wenqi, Z.; Yong, L.; Yingjuan, S.; Hao, L. Experimental research of gas-solid flow behaviors in pressurized circulating fluidized bed-I: Solid holdup distribution. J. Southeast Univ. 2012, 42, 308-312.

63. Wang, Q.; Rong, N.; Fan, H.; Meng, Y.; Fang, M.; Cheng, L.; Cen, K. Enhanced hydrogen-rich gas production from steam gasification of coal in a pressurized fluidized bed with $\mathrm{CaO}$ as a $\mathrm{CO} 2$ sorbent. Int. J. Hydrog. Energy 2014, 39, 5781-5792. [CrossRef]

64. Han, W.; Fang, J.; Liu, Z.; Tang, J. Techno-economic evaluation of a combined bioprocess for fermentative hydrogen production from food waste. Bioresour. Technol. 2016, 202, 107-112. [CrossRef] [PubMed]

65. Cristóbal, J.; Caldeira, C.; Corrado, S.; Sala, S. Techno-economic and profitability analysis of food waste biorefineries at European level. Bioresour. Technol. 2018, 259, 244-252. [CrossRef] [PubMed] 